WIDER Working Paper 2018/163

Wage growth and inequality in urban China

1988-2013

Björn Gustafsson ${ }^{1}$ and Haiyuan $\mathrm{Wan}^{2}$

December 2018 


\begin{abstract}
We investigate the evolution of wage levels, wage inequality, and wage determinants among urban residents in China using China Household Income Project data from 1988, 1995, 2002,2007 , and 2013. Average wage grew impressively between each pair of years. Wage inequality had long been on the increase, but between 2007 and 2013 no clear changes occurred. In 1988, age and wages were positively related throughout working life, but more recently older workers' wages have been lower than those of middle-aged workers. The relationship between education and wages was weak in 1988 but strengthened rapidly thereafter-a process that came to a halt in 2007. During the period in which China was a planned economy the gender wage gap was small in urban China, but it widened rapidly between 1995 and 2007. We also report the existence of a premium for being employed in a foreign-owned firm or in the state sector.
\end{abstract}

Keywords: wages, wage inequality, wage growth, wage functions, urban China, labour market JEL classification: J31, P23, P31

Acknowledgements: This is a revised version of a paper presented at a workshop as part of the UNU-WIDER project 'Inequality in the Giants: China', held at Beijing Normal University, Beijing, China, on 15 May 2018. We thank our discussant Deng Quheng and other participants for constructive comments.

1 Department of Social Work, University of Gothenburg, Gothenburg, Sweden, corresponding author: bjorn.gustafsson@socwork.gu.se; ${ }^{2}$ Haiyuan Wan, Business School, Beijing Normal University, Beijing, China.

This study has been prepared within the UNU-WIDER project on 'Inequality in the giants'.

Copyright (C) UNU-WIDER 2018

Information and requests: publications@wider.unu.edu

ISSN 1798-7237 ISBN 978-92-9256-605-0 https://doi.org/10.35188/UNU-WIDER/2018/605-0

Typescript prepared by Luke Finley.

The United Nations University World Institute for Development Economics Research provides economic analysis and policy advice with the aim of promoting sustainable and equitable development. The Institute began operations in 1985 in Helsinki, Finland, as the first research and training centre of the United Nations University. Today it is a unique blend of think tank, research institute, and UN agency — providing a range of services from policy advice to governments as well as freely available original research.

The Institute is funded through income from an endowment fund with additional contributions to its work programme from Finland, Sweden, and the United Kingdom as well as earmarked contributions for specific projects from a variety of donors.

Katajanokanlaituri 6 B, 00160 Helsinki, Finland

The views expressed in this paper are those of the author(s), and do not necessarily reflect the views of the Institute or the United Nations University, nor the programme/project donors. 
This paper examines how wages, wage inequality, and wage determination among urban residents in China have evolved over the 25-year period from 1988 to 2013, a period as long as one generation. At the beginning of this period China was a closed, low-income economy with administrative allocation of labour in which almost all men and women of work-active ages were employed by the state sectors. Since then, the policy of opening up, and the increased foreign demand that followed from it, initiated rapid economic growth, which came to be maintained by China's high rate of investments and rapidly increased domestic demand.

During the second part of the 1990s, reforms changed the relationship between work units and workers in urban China. The lifelong relationships between workers and work units were broken and many workers were allocated by the market at wages that, to a large extent, reflected market conditions. During the same period many workers became unemployed, while others left the labour force. Employment in private firms and self-employment increased rapidly. Meanwhile, the composition of the labour force changed due to the very rapid expansion of higher education. Urban China has also experienced a large inflow of migrants with rural hukou (residential permit). Such migrants are typically less qualified than the local residents with urban hukou, and compete with urban residents for jobs paying low wages. However, more recently the number of migrants living in urban China has stabilized, and their qualifications have tended to be less different from those of urban residents than was formerly the case.

This paper aims to tell the story of how workers' wages, wage inequality, and the incidence of relatively low wages have changed. We also aim to show how wage levels and the association between different characteristics of the worker and wages have varied. What makes our study different from previous ones in the literature is the longer period of study. The data we use are taken from the China Household Income Project (CHIP) for the years 1988, 1995, 2002, 2007, and 2013. ${ }^{1}$

We draw several conclusions from the study. The first is that average wage growth among urban residents in China has been very impressive. Expressed in constant prices using the Urban Consumer Price Index (CPI) provided by the National Bureau of Statistics, average wages were as much as about ten times as high in 2013 as in 1988. While wage growth in high-income countries was disappointing during the Great Recession that started in 2007, average wages in urban China grew remarkably rapidly from 2007 to 2013 . The second conclusion is that wage inequality among urban residents was for a long time on a trajectory of increase. However, we report that the trend of increased wage inequality did not continue after 2007.

The third conclusion is that during the planning period, the combination of wage scales favouring seniority and the very low mobility of workers led to a strong positive relationship between age and wages that continued throughout working life. However, this has changed, and more recently the wages of older workers have been lower than those of middle-aged workers with the same characteristics. Consistent with this, the incidence of relative low wages has increased rapidly for older workers. During the planned-economy period, the relationship was weak between workers' length of education and wages in urban China-much weaker than in high-income countries. We therefore confirm as a fourth conclusion that after 1988 and until 2007, the relationship between length of education and wages grew stronger and stronger. This development can be seen from the perspective of changed wage-setting mechanisms, in combination with the rapid increase in the

\footnotetext{
${ }^{1}$ See http:/ / ciid.bnu.edu.cn/chip/index.asp?lang=EN.
} 
number of less-qualified workers due to in-migration and the rapidly increased demand for skilled labour. However, after 2007 this trend did not continue. This is consistent with the changed supply of workers with different qualifications, for example due to a rapid expansion of higher education in China.

The fifth conclusion is that in 1988, urban China had an internationally low gender wage gap. However, the development thereafter was less favourable for women than for men. The gap in labour force participation rate between women and men widened, more men than women moved into self-employment, and the gender wage gap grew rapidly from 1995 to 2007, although not thereafter. The sixth conclusion is that workers in state-owned units or employed in foreign-owned firms enjoy a wage premium compared with workers with similar characteristics employed under other types of ownership. In the paper we also show how wages have varied by, for example, region, membership in the Communist Party of China, and ethnic status.

The rest of the paper is laid out as follows. A survey of literature on wages in urban China is found in the next section. Section 3 deals with data and variable definitions. In Section 4 we report the overall development of wage levels, wage inequality, and relatively low wages from 1988 to 2013. In Section 5 we describe how, for the same period, wages have varied along various dimensions, emphasizing age, education, gender, and ownership. In Section 6 we specify and estimate wage functions for each of the years 1988, 1995, 2002, 2007, and 2013 and discuss the results. Finally, we sum up the study and its main findings in Section 7.

\section{The literature}

Knowledge on wage inequality and determinants of wages in urban China was for a long time fragmented. However, today much more is known on the situation in 1988 and the years thereafter. Contributions have been made by economists as well as by sociologists. In the literature published in the early 1990s and thereafter, various research questions have been asked in studies that have come to cover increasingly longer periods. A reader of the publications also sees how new econometric techniques have come into use. A prerequisite for the literature is that relevant data have been available to use.

Contributing to the start of this literature was the survey of urban residents made as a part of the China Household Income Project (CHIP) for the year 1988. For the first time, this enabled researchers to use microdata collected all over urban China to study wage levels, wage inequality, and wage determinants. The urban sample for CHIP was drawn from the Urban Household Survey (UHS), which has long been carried out by the National Bureau of Statistics (NBS) with the purpose of producing official statistics for China. However, at the end of the 1980s the microdata from UHS covering large parts of the country were not available to researchers.

Earnings information in CHIP relates to the specific years 1988, 1995, 2002, 2007, 2008, and 2013. The different waves of CHIP surveys are drawn from the annual UHS and use similar definitions. Therefore, it is not surprising, but it is reassuring, that studies on wage inequality and wage determinants that have used CHIP and UHS report results that typically agree. ${ }^{2}$ In addition to

\footnotetext{
${ }^{2}$ Examples of studies based on UHS are $\mathrm{Ng}$ (2007), who, like Chi and Li (2008), studied the gender income gap, and Chi et al. (2011), who studied the increase in earnings inequality between 1987 and 1996 and between 1996 and 2004. Han et al. (2012) investigated globalization (as indicated by Deng Xiaoping's 1992 southern tour and the 2001 World Trade Organization accession) and wage inequality in the period 1988-2008. The results indicated that workers in the higher positions of the wage distribution benefited more from globalisation than those in the lower part of the wage distribution. Ge and Yang (2014). analysed data for the period 1992-2007 using a production function framework and
} 
these, data surveys initialized by researchers have been used to study the extent and evolution of wage inequality and the association between characteristics and wages. ${ }^{3}$

Results from the 1988 urban CHIP survey on wage inequality and characteristics related to wages were published in, for example, Knight and Song (1993) and Xie and Hannum (1996). The 1988 CHIP survey has also been used as a benchmark for several studies that have investigated how wage inequality and wage determinants have changed over time. A first opportunity came with the 1995 wave, and the results showed that wage inequality had increased rapidly since 1988. Such studies include Gustafsson and Li (2001), Knight and Song (2003), Shu and Bian (2003), and Hauser and Xie (2005). When the third wave of CHIP was produced for 2002 it became possible to investigate a second period. Results for this period also show a rapid increase in wage inequality: see Appleton et al. (2005b), Knight and Song (2008), and Deng and Li (2009). The last-mentioned study is an early example of the application of regression-based decomposition to the study of wage inequality in urban China. A fourth wave of CHIP collected data for 2007 and 2008, and again wage inequality was found to have increased rapidly. Examples of publications reporting this are Xing and Li (2012), who investigated how residual wage inequality evolved from 1995 to 2007, and Deng and Li (2012), who focused on low earnings. A third example is Appleton et al. (2014), who covered the entire period from 1988 to 2007. Our study is the first we are aware of that has also used the 2013 wave of CHIP.

The urban survey of CHIP has also been used to compare wage inequality and wage determination in urban China with their counterparts in other countries, namely Russia, India, and Vietnam. An early example is Gustafsson et al. (2001), who compared wages in urban China in 1988 to those in urban Russia, reporting similar levels of wage inequality in the two countries. The gender wage gap was found to be smaller in urban China, where the association between years of schooling and wages was weaker than in urban Russia. In contrast, seniority played a larger role for wage levels in urban China than in Russia. Gustafsson et al. (2015) made a similar comparison using Chinese data for 2002 and Russian data for 2003, and were thus able to look at changes since the end of the 1980s. The results showed that wage inequality had risen equally rapidly in the urban regions of both countries, and the association between years of schooling and earnings had strengthened. Another finding was that the gender wage gap continued to be smaller in urban China than in urban Russia.

Bargain et al. (2009) compared wages and wage determinants in urban China and urban India using (for China) CHIP data for the years 1988, 1995, and 2002. Workers in India were found to have had an advantage in real wages at the end of the 1980s, but thereafter the wages of Chinese workers had developed more favourably. These findings are consistent with the more rapid general economic development in China, as well as with the more rapid increase in the educational level of workers in China than in that of workers in India. Lee and Wie (2017), who compared the evolution of the gender wage gap in urban China and urban India in the 1990s and 2000s, report increases in

report that capital accumulation, skill-based technical change, and rural-to-urban migration all contributed to the increase in earnings inequality. Further examples are Meng et al. (2013), who investigated male wages from 1988 to 2009, and Meng (2012), who, using UHS data for 1998-2009, report, for example, the development of wage inequality; and Feng et al. (2017), who report on how labour force participation and unemployment in urban China developed from 1998 to 2013.

${ }^{3}$ Examples include two surveys made for 1993 analysed by Wu (2002). Other early examples can be found in Wu and Xie (2003), who used the 1996 'Life Histories and Social Change in Contemporary China' survey, and Xie and Wu (2008), who used a survey conducted 1999 in Shanghai, Wuhan, and Xian. Another relatively early example is Zhao (2002), who studied earnings differentials between state and non-state enterprises using a household survey for 1996 conducted in six provinces. Still another example is Zhou (2014). who used the Life History and Social Changes in Contemporary China survey and the 2010 wave of the Chinese General Social Survey to investigate returns to education and the rise of earnings inequality from 1996 to 2010. 
China but decreases in India. Cai and Liu (2015) used CHIP data for 2002 and a similar Vietnamese survey to compare male wages in urban China with male wages in urban Vietnam, and female wages among urban Chinese women with those of their counterparts in urban Vietnam, over the entire wage distribution. The gaps, when expressed in internationally comparable purchasing power, were found not to be uniform across the wage distribution, and the pattern differed between female and male workers. On average, urban Chinese workers earned a higher wage than their on average younger Vietnamese counterparts. The wage gap between state and private enterprises was much larger in China than in Vietnam.

Several dimensions of wage differentials in urban China have been analysed. One key topic has been the relationship between education and earnings. This was found to be weak during the 1980s: see for example Johnson and Chow (1997) and Liu (1998), both using CHIP 1988. The same two studies also show a strong association between experience and wage which, in a reality with very little labour mobility, stands for seniority. The subsequent increase in the association between education and wage and the changed shape of the experience/earnings profile has been well documented in the literature. Examples include Maurer-Fazio (1999); Yang (2005), who analysed CHIP 1988 and 1995; Zhang et al. (2005), who used each annual survey of the UHS for the period from 1988 to 2001; Wang (2012, 2013), who used CHIP 1995 and 2002; Zhou (2014), who analysed data for 1996 and 2010; and Gao and Smyth (2016), who analysed UHS for 2001, 2005, and 2010. An increased association between education and wages has also been found in many other countries that have changed from a planned to a market economy: see Fleisher et al. (2005).

Another key topic in the literature has been the gender wage differential. The early study by Gustafsson and Li (2000) using CHIP data for 1988 and 1995 showed a relatively small gender wage gap which remained relatively unchanged across these two years. Wage function analysis showed the existence of an unexplained gender wage gap. Also analysing CHIP data for 1988 and 1995, Shu and Bian (2003) and Démurger et al. (2007) reached conclusions similar to those of Gustafsson and Li (2000). Applying quantile regressions to the same data, Bishop et al. (2005) report the largest unexplained gender wage gap at the lower part of the wage distribution. As is well known, the unexplained gender wage gap can be attributed to gender discrimination but also to unmeasured characteristics associated with wages that vary by gender. Against this background, it is interesting that Xu et al. (2006) report, from a survey of workers in two cities in Zhejiang, that many but not all respondents stated that they had experienced gender discrimination in employment decisions and in wage setting.

However, when a restructuring of the state-owned enterprises (SOEs) began and the lifelong relationships between work units and workers was terminated, female workers were more affected than male workers. This shows up in the fact that labour force participation among married women fell more rapid than among men (see, for example, Hare 2016). The decreased labour force participation among women can be attributed to a return to more traditional gender roles which correlates with a decreased availability of day care for children (see Du and Dong 2013).

One of the first studies to report a widened gender wage gap in urban China was Ng (2007), who used UHS data with the latest observation referred to being from 1997. Consistent with this and also using UHS, Zhang et al. (2008a) report a fall in the average female wage compared with the average male wage from 86 per cent in 1988 to 76 per cent in 2004. Chi and Li (2008), who analysed UHS data for the years 1987, 1996, and 2004, report that the largest increase in the gender wage gap had taken place at the lowest quintiles of the wage distribution. When analysing changes between 1995 and 2002, Li and Gustafsson (2008) focused on how the gender gap among labour market participants and early retirees had developed. They report a widening trend that to a large extent could be attributed to the fact that the labour market situation had worsened more for women than for men. Liu (2011), based on an analysis of the China Health and Nutrition Survey 
from 1989 to 2004, is another study reporting a large increase in the gender wage gap. Li and Song (2013) report, from analysing CHIP data for 1995, 2002, and 2007, that the gender wage gap widened significantly between the two pairs of years. Zhang and Hannum (2015), in a study of the period 1989-2009, draw attention to the fact that it is married women, not single women, who have experienced increased gender wage gaps. ${ }^{4}$ In a new study using CHIP data up to 2013 and focusing on workers aged 25 to 49, Song et al. (2017) report that the rapid increase in the gender gap that occurred between 2002 and 2007 was followed by a slight decrease from 2007 to 2013, indicating that the trend of increasing gender wage gap has come to a (perhaps temporary) halt.

Another dimension of the workforce to focus on has been the relationship between the ownership of the work unit and wages. Chen et al. (2005), who used CHIP data for 1995, contrasted four forms of ownership - centrally owned SOEs, locally owned SOEs, collectively owned firms, and foreign-invested firms — analysing wages as well as hours worked. The results provide evidence that the Chinese labour market in 1995 was not fully integrated with regard to domestic enterprises, in the sense that those employed in SOEs at the central or provincial level enjoyed a wage premium. In an analysis using CHIP data for 1995 and 2002, Démurger et al. (2006) contrasted five types of ownership: SOEs, collectively owned, private and individually owned, foreign-invested, and government institutions. The authors concluded that segmentation of the urban Chinese labour market by ownership had actually increased between the years studied. However, when analysing the same categories of ownership for the period from 2002 to 2007, Démurger et al. (2012) reached the opposite conclusion for this period. Related to those studies is Wu (2010), who analysed job mobility using data collected in ten cities in 2010. There is also Chen et al. (2011), a study that concentrates on foreign-owned firms using data from the First National Census in 2004. These authors found results consistent with those of studies in other countries: a premium for being employed in the foreign-owned sector on both wage and non-wage compensation. Still another study on work unit ownership and wages is Whalley and Xing (2016), who used CHIP data for 1995, 2002, and 2007. These authors report that while over this period wage dispersion was higher in the private sector, it increased faster in the public sector. According to this study, a majority of the increase in urban wage inequality is associated with labour reallocation from the public to the private sector.

In addition to wage differences according to age, education, gender, and ownership of work unit, differences along several other dimensions have been studied in the literature, although perhaps not as intensively. One such difference studied is regional variation, for example by dividing urban China into a few large regions. China was first opened up in the eastern or coastal region of the country, and during some periods wage growth has been larger in this region than elsewhere. Therefore, it is typically shown that wages are higher in the coastal region. It has also been shown that members of the Communist Party of China (CPC) have higher wages than other workers with the same characteristics: see, for example, Appleton et al. (2005a). However, it is far from clear if this is a causal relationship, as membership of the CPC is subject to choice by workers and by the party. On this, see Li et al. (2007), who analysed twin data and conclude that CPC party members fare well not because of their political status but because of the superior ability that made them become CPC members.

A further dimension that has attracted attention is the ethnic status of the worker. For example, in a study based on the micro-census for 2005 in which different ethnic minorities can be identified, Gustafsson and Yang (2017) report examples of specific minorities earning more than, equal to, or less than Han workers. The same study also reports examples of three different changes over time

\footnotetext{
${ }^{4}$ See also Zhang et al. (2008b), who, using the China Urban Labor Survey/China Adult Literacy Survey, conducted in 2004/05 in five large cities, report that married female workers earn considerably lower wages than married male workers.
} 
in ethnic earnings premiums vs earning penalties: one ethnic minority for whom development has been more favourable than for the Han majority; a second category for which development has been similar; and a third category for which development has been unfavourable. In contrast, other studies that, due to the data used, cannot distinguish between different minorities in urban Chinasuch as Ding et al. (2013), who used CHIP 1995, 2002, and 2007-report small gaps between the average wages of ethnic minority workers and Han workers.

\section{Data, assumptions, and dimensions of the labour force}

We use CHIP data for the five years 1988, 1995, 2002, 2007, and 2013 from the same 12 provinces: Beijing, Shanxi, Liaoning, Jiangsu, Anhui, Henan, Hubei, Guangdong, Chongqing, Sichuan, Yunnan, and Gansu. Our samples were subsamples taken from the samples used by the NBS when obtaining the official household statistics published in the annual Statistical Yearbook of China, the UHS. The NBS also carried out the fieldwork. For the descriptive tables and figures reported in the next section we used sample weightings that have been developed by members of the CHIP team to account for the fact that sample probabilities were not the same in all provinces covered by CHIP.

The population under study is wage earners who have urban hukou. In the earlier waves of CHIP there are only a few observations of holders of rural hukou earning wages. However, due to the changed sampling strategy of NBS when selecting respondents, a somewhat larger number of rural hukou holders are observed in CHIP 2013. In order to have good comparison across the years we have excluded observations with rural hukou from the samples under study. ${ }^{5}$

A person is classified as a wage earner based on questions posed in the CHIP questionnaire. In a few cases (for example, 30 observations in the 2013 data) a person is recorded as a wage earner and also as self-employed. In such case is the stated work time and income of the two alternatives that are compared, and if wage employment dominates we classify the person as a wage earner. A wage earner can, in our analysis, be of any age from 16 to 70 -although few are over the statutory retirement age, which is typically 55 for women and 60 for men. The size of the sample under study varies from, at most, around 17,000 in 1988 to 7,000 in 2013. In Table 1 we show that among people aged 16 to 70, the self-employed were very few in 1988 and the proportion had not grown to more than 5 per cent by 2002. However, thereafter the increase has been very rapid, and in 2013 no less than 20 per cent were self-employed. The other side of this development is that wage earners make up smaller and smaller proportions of those aged 16 to 70; in 2013 they made up no more than 52 per cent of all people in this age category.

Wages in this study are measured for the accounting period of one year and include regular wages, overtime compensation, allowances, and bonuses. We have chosen this accounting period because in the questionnaire for 1995 , only question on yearly wages was posed. ${ }^{6}$ Using the CPI, we measure earnings in constant 2013 prices. In Section 5 of this paper we introduce the various dimensions

\footnotetext{
${ }^{5}$ It should be understood that UHS, for a long time, did not cover rural-to-urban migrants. However, some authors have used migrant samples collected in CHIP to study earnings among rural residents living in urban China and compare them with earnings among urban residents. Examples include Démurger et al. (2009), Zhu (2016), Qu and Zhao (2017), Zhang and Wu (2017), and Ma (2018).

${ }^{6}$ The other waves of CHIP also included questions on weekly and monthly wages, as well as questions on working time.
} 
by which the population of wage earners is disaggregated in this investigation. However, the next section starts with a look at the overall development of wage levels, wage inequality, and low wages.

Table 1: Distribution of employment categories: 1988, 1995, 2002, 2007, and 2013 (\%)

\begin{tabular}{lrrrrr}
\hline & $\mathbf{1 9 8 8}$ & $\mathbf{1 9 9 5}$ & $\mathbf{2 0 0 2}$ & $\mathbf{2 0 0 7}$ & $\mathbf{2 0 1 3}$ \\
Not employed & 25.4 & 28.3 & 30.5 & 31.8 & 28.4 \\
Wage earners & 73.2 & 69.5 & 64.8 & 56.3 & 51.8 \\
Self-employed & 1.4 & 2.2 & 4.6 & 11.9 & 19.8 \\
\hline
\end{tabular}

Note: The labour force is limited to people aged 16 to 70.

Source: Authors' computations based on CHIP urban surveys.

\section{Overall development}

Figure 1: Wage distribution in 1988, 1995, 2002, 2007, and 2013

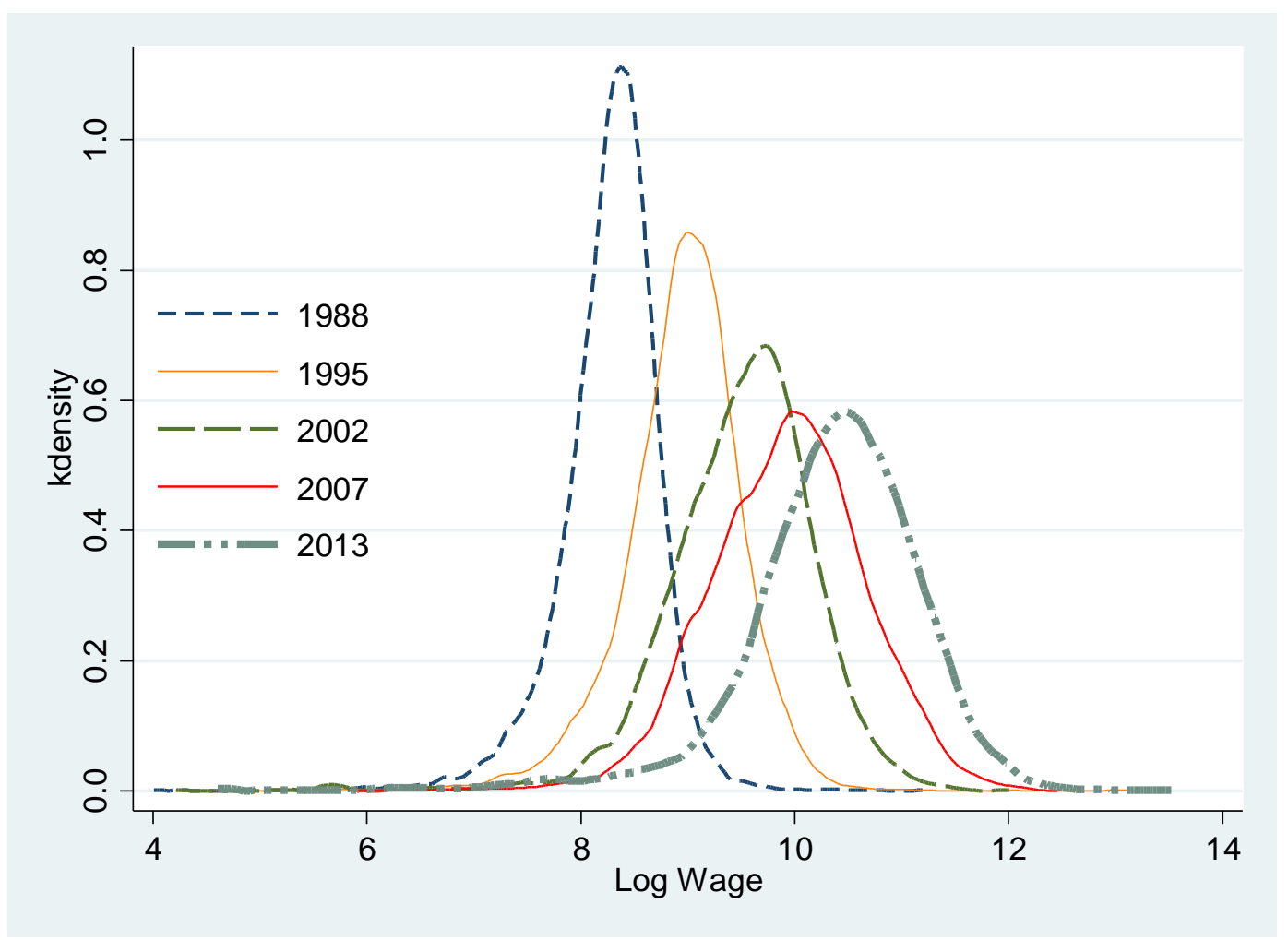

Source: Authors' estimates and illustration, based on CHIP urban surveys.

In Figure 1 we show kernel densities for the natural log of wages (ln) estimated for each of the five years under study. The figure very clearly illustrates that wages have grown rapidly between each pair of years under study. This means that rapid growth took place also from 2007 to 2013, when high-income countries were hit by the Great Recession. ${ }^{7}$ We also see that between most years under study the distribution became more unequal. However, this development came to a halt in 2007.

\footnotetext{
${ }^{7}$ This is consistent with Yang and Li (2017), who conclude that the Great Depression did not have significant negative impact on wage growth in China. Their study was based on data from the Longitudinal Survey on Rural-Urban Migration in China (RUMiC) for 2008, 2009, and 2010.
} 


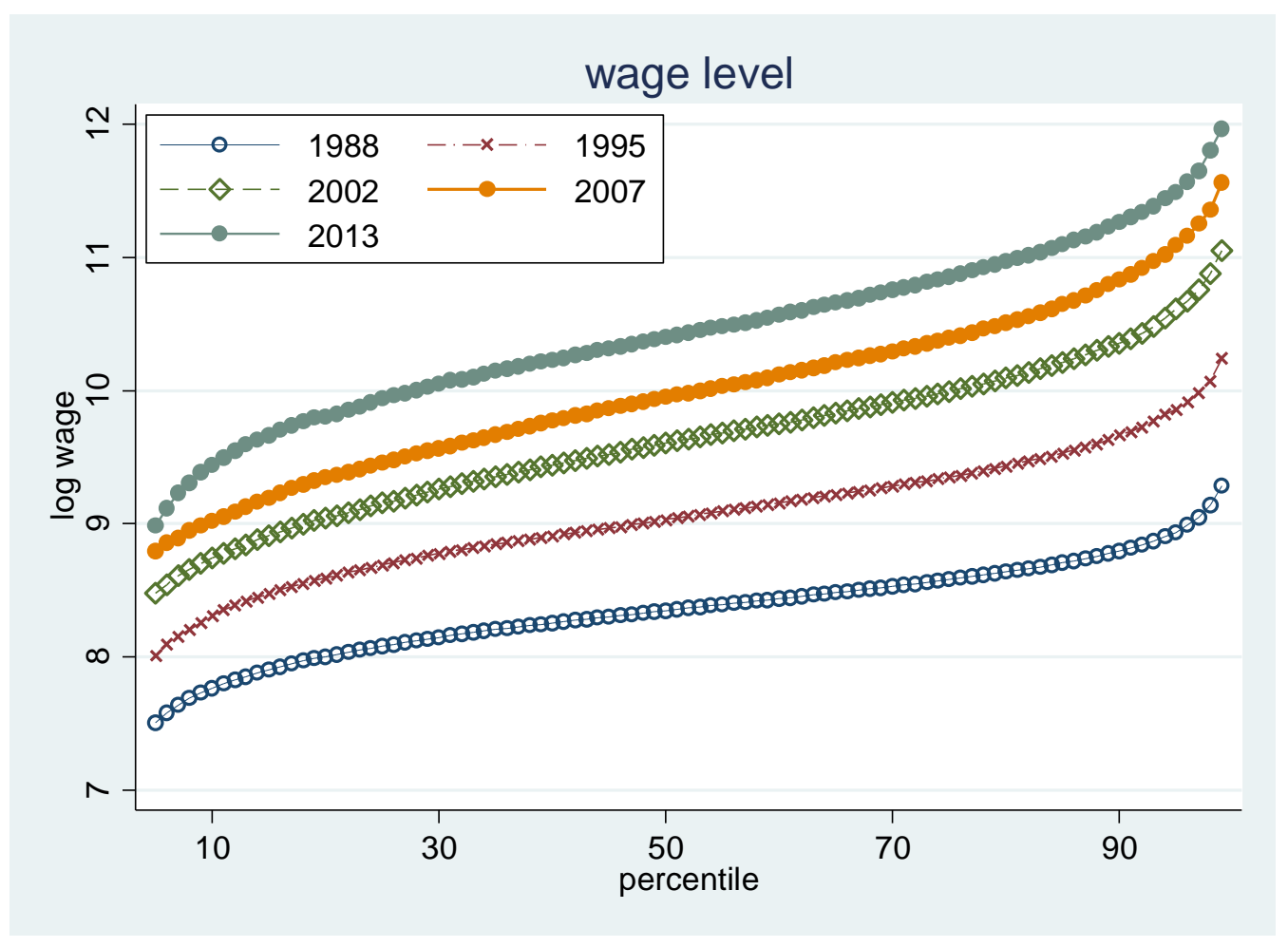

Source: Authors' computations based on CHIP urban surveys.

Figure 2 is an alternative representation of the changes: along the horizontal axis we show centiles of the wage distribution and along the vertical axis are log wages. Each subsequent curve is above the previous one, indicating that real wages have been increasing at all positions of the wage distribution. In Figure 3 we take still another view of the development by showing growth curves for each subperiod (Ravallion and Chen 2003). Along the horizontal axis we show the position of the wage distribution and along the vertical axis is the percentage change since the previous survey, measured as an annual rate. Several comments can be made. First, the growth rates are, by international standards, impressive. Take the median as the point of reference: annual growth was around 10 per cent between 1988 and 1995 and 8 per cent during all following subperiods. Second, wage growth has not been equal along the wage distribution. For the first three periods the patterns are extraordinarily clear: growth was fastest at the top of the distribution, slowest at the bottom. For example, during the period 1995-2002, a period when many workers left the labour force and others became unemployed, wages grew by around 6 per cent at the bottom of the distribution but around 10 per cent at the top of the distribution. From this pattern of unequal growth, the period 2007-13 is an exception, as growth was similar along most of the distribution, with the exception of lower growth at both tails. 
Figure 3: Annual wage growth by percentile

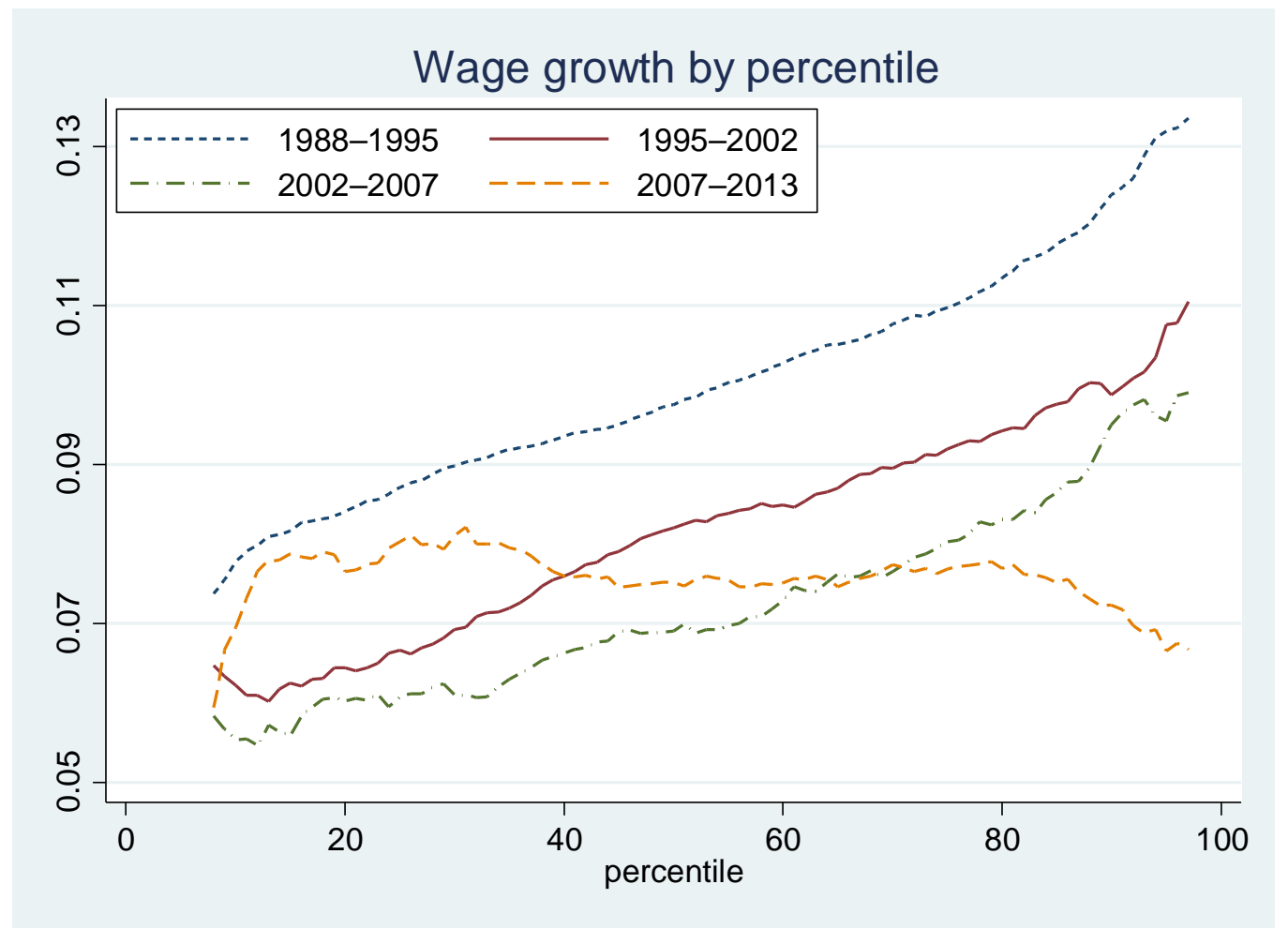

Notes: (1) Wages in this paper are shown in log form, deflated to the year 2013; (2) we have applied sample weightings; (3) the figure shows annual growth rate.

Source: Authors' computations based on CHIP urban surveys.

Inequality measures for the various years under study provide numerical values that also illustrate the rather large increases in wage inequality up to 2007. Table 2 shows, for example, that the Gini coefficient went from 0.23 in 1988 all the way up to 0.38 in 2007 - a rather rapid increase. However, the Gini for 2013 was also estimated at 0.38 , although the numerical values for the other income inequality measures reported in the same table show higher values for 2013 than for 2007. We can thus conclude that the episode of generally increasing wage inequality had come to a (perhaps temporary) stop in 2007.

Table 2: Wage inequality in 1988, 1995, 2002, 2007, and 2013

\begin{tabular}{llllll}
\hline & $\mathbf{1 9 8 8}$ & $\mathbf{1 9 9 5}$ & $\mathbf{2 0 0 2}$ & $\mathbf{2 0 0 7}$ & $\mathbf{2 0 1 3}$ \\
Gini & 0.230 & 0.301 & 0.345 & 0.379 & 0.384 \\
CV & 0.500 & 1.040 & 0.702 & 0.788 & 0.871 \\
Theil & 0.098 & 0.190 & 0.202 & 0.245 & 0.263 \\
MLD & 0.102 & 0.167 & 0.213 & 0.250 & 0.282 \\
\hline
\end{tabular}

Note: Sample weightings are used.

Source: Authors' computations based on CHIP urban surveys.

When digesting these results, it should be remembered that they relate to the wages of individuals, not income received by households. Although wages are on average the single largest income source, other sources also make consumption possible. Examples of other income sources are pensions, other transfers from the public sector, self-employment income, and income from capital. Income taxes can also affect the disposable income of a household. When studying household income, the analyst typically adds together all incomes received by all household members and also takes into account how many members live within the household. Actually, while 
we here report that the Gini for wages among wage earners remained unchanged between 2007 and 2013, the Gini for household income per capita in urban China, obtained from the same surveys, clearly increased (see Gustafsson and Ding 2017).

We now turn to the development at the lower positions of the wage distribution. A 'minimum wage regulation' was first put in place by China in 1984. Afterwards, China formally launched the Labour Contract Law of China in 1994 to confirm the minimum wage regulation by legislation. Some cities in China began to implement the minimum wage policy after 1995. However, as result of unbalanced employer-employee power and an imperfect collective bargaining system, it is well known that enterprises widely escaped from implementing the regulation at that time. Most important of all, in practice the minimum wage regulation in China is not detailed enough to implement when enterprises do not follow the law, as there are few measures to punish enterprises if they break the regulation (Ding 2010).

In light of these problems, and in order to protect workers' benefits, a revised minimum wage regulation was launched in 2004 to better guarantee the implementation of the minimum wage policy. Since then the minimum wage level has steadily increased. Currently, the minimum wage is widely settled nationally, and refers to the lowest hourly or monthly remuneration that employers must legally pay to workers. ${ }^{8}$ Calculating the minimum wage changes from the aggregate data released by the Ministry of Human Resources and Social Security, the annual growth rate of the minimum wage during 1994-2004 was 7 per cent, while during 2005-13 it was even higher, at about 11 per cent. Furthermore, looking at regional minimum wage growth during the period 2005-13, we find that the adjustment of the nominal minimum wage level is really larger than that of its counterpart during the period 1994-2004 (MHRSS 2016).

Table 3: Measures of low pay: 1988, 1995, 2002, 2007, and 2013

\begin{tabular}{lrrrrr}
\hline & $\mathbf{1 9 8 8}$ & $\mathbf{1 9 9 5}$ & $\mathbf{2 0 0 2}$ & $\mathbf{2 0 0 7}$ & $\mathbf{2 0 1 3}$ \\
Low-pay thresholds, Yuan & $2,815.1$ & $5,572.7$ & $9,894.2$ & $13,975.7$ & $21,945.5$ \\
Low-pay incidence, per cent & 16.7 & 21.6 & 27.2 & 28.8 & 27.6 \\
Mean wage of the high paid, Yuan & $4,943.1$ & $11,098.0$ & $21,610.7$ & $33,125.4$ & $51,605.1$ \\
Mean wage of the low paid, Yuan & $2,058.3$ & $3,928.7$ & $6,766.5$ & $9,391.1$ & $13,814.0$ \\
Ratio of high/low paid & 2.4 & 2.8 & 3.2 & 3.5 & 3.7 \\
\hline
\end{tabular}

Notes: (1) Wages are deflated to the year 2013; (2) sample weightings are used; (3) low-paid workers are defined as those receiving a wage that is less than two-thirds of the median wage (as observed the same year).

Source: Authors' computations based on CHIP urban surveys.

Against this background, we report what our data show on the evolution of low wages in urban China. Following measures often used in the international literature on low earnings, and also in the Chinese context by Deng and Li (2012), we show information on relatively low wages among urban residents in China for the period 1988-2013 in Table 3. A low wage is here defined as an annual wage that is less than two-thirds of the median wage observed in each year. The table shows that the incidence of low relative wages increased from 17 per cent in 1988 to 27 per cent in 2002, after which further changes were very small. ${ }^{9}$ This indicator thus illustrates that the increasing trend in the incidence of low wages ended around the beginning of the new millennium. However, the

\footnotetext{
${ }^{8}$ Its definition excludes overtime pay, special subsidy for odious working conditions, and all kinds of non-monetary income including social insurance benefits.

${ }^{9}$ According to Lin and Yun (2016), who used a panel of city-specific minimum wages and studied the period 2004 09 , increasing the minimum wage reduces wage inequality by decreasing the wage gap between the median and the bottom decile over the period studied.
} 
gap between average wages among low-wage earners and the average of non-low-wage earners has continued to widen substantially since 2002 .

\section{$5 \quad$ Wages by dimensions of the labour force}

In urban China, wages vary by a number of dimensions. Here we are going to give most attention to four: age, education, gender, and ownership of the work unit. In addition, we consider region, ethnicity, and membership of the CPC. We have computed tables showing how participation rates (the sum of workers, the self-employed, and the unemployed in the population) vary by each dimension, how the population of wage earners is composed, and incidence of low wages. This information for each year studied is found in the Appendix to the paper. In the text we comment on aspects and changes we deem most interesting, and display a number of figures. This section also functions as a background for the next section, in which we report the results of estimating wage functions for each year under study.

Starting with age, one can observe from Table A2 that between 1988 and 2002, increasingly fewer people under 25 were wage earners in urban China. A background to this is the higher proportion of young adults remaining in education. Few people in urban China work after the statutory retirement age of 55 . The population of Chinese wage earners has been ageing, a process that mostly had taken place by 2002. Figure 4 illustrates that across all pairs of survey years, the average $\log$ wage of workers with different length of experience increased. The figure also shows a tendency of compression in the profile of wages by experience across the surveys. In the profile for 1988, the maximum average wage was reached among those with the longest experience, but the maximum has thereafter been achieved by those with shorter experience.

Figure 4: Log wage level by years of experience

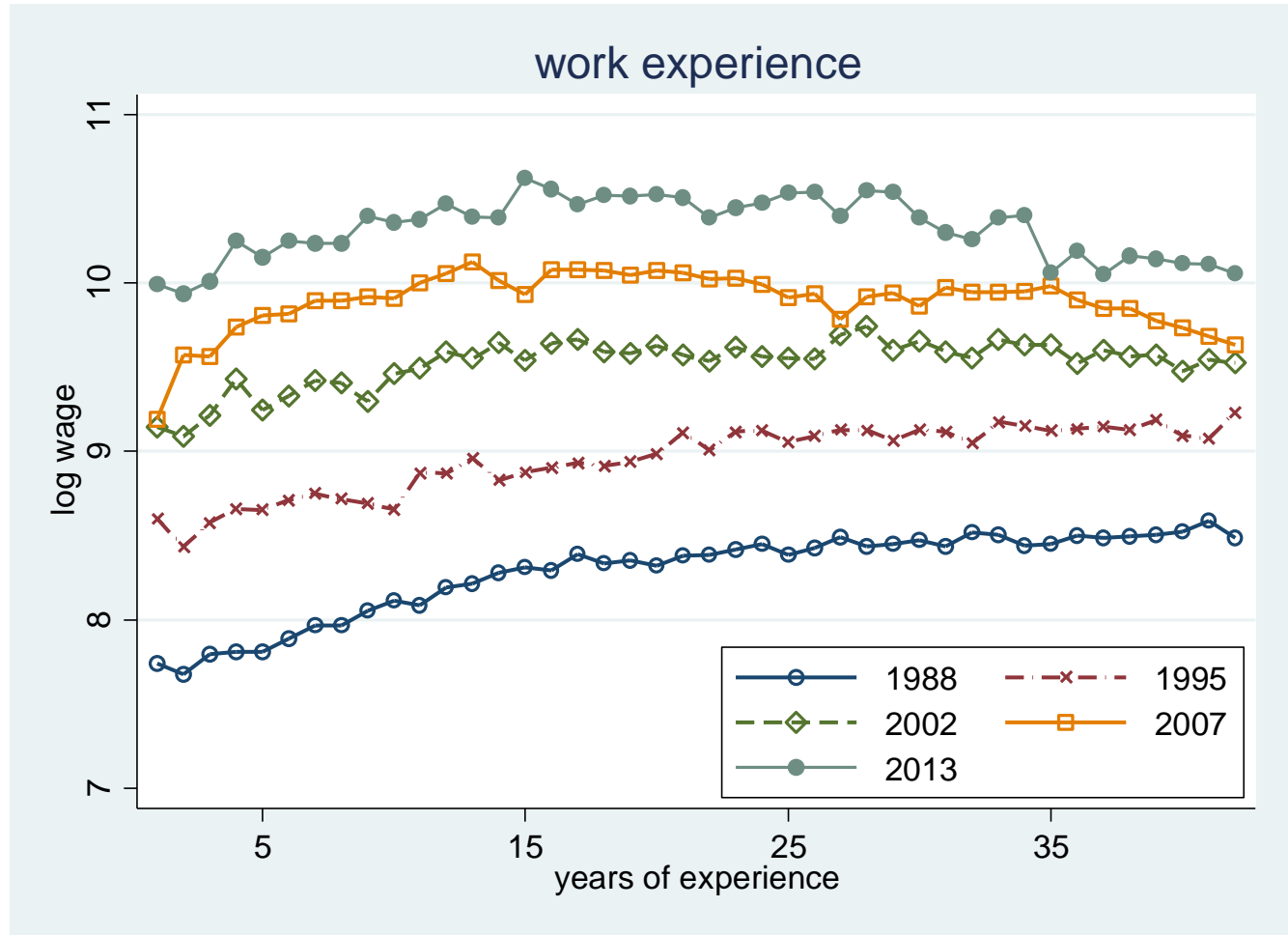

Source: Authors' computations based on CHIP urban surveys. 
Figure 5 directly shows that it was between 1995 and 2002 - the period of large-scale reorganization of how labour was allocated in urban China, when the labour force participation rate decreased and the unemployment rate increased-that the relative wages of workers aged 55+ fell dramatically. The incidence of low wages among workers aged 55+ went from 6 per cent in 1988 to 30 per cent in 2002 and further to 41 per cent in 2013 (see Table A3).

Figure 5: Relative wages for workers of various ages

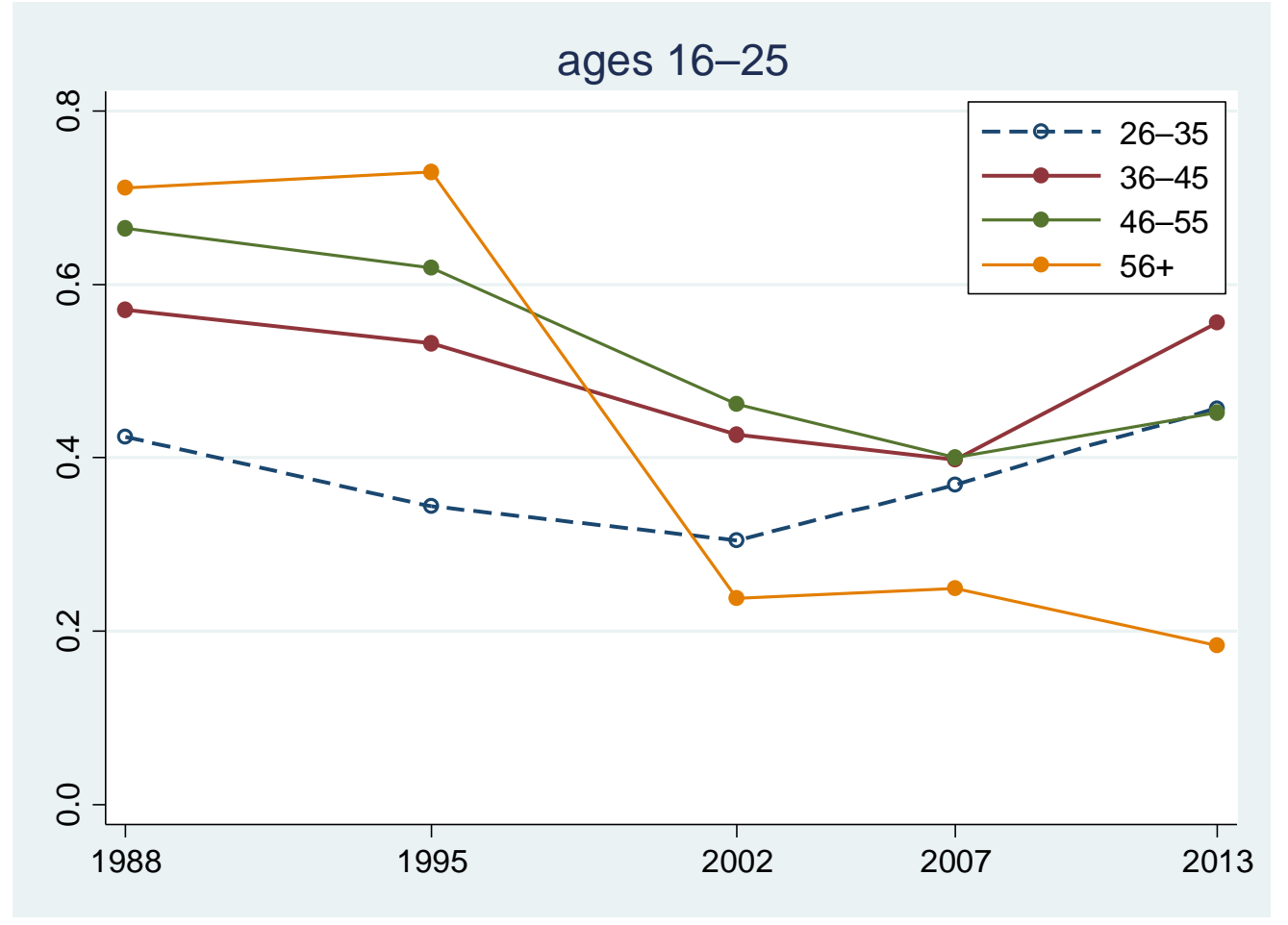

Note: ' 0 ' is the average wage of workers aged 16-25.

Source: Authors' computations based on CHIP urban surveys.

As in many high-income countries, a steady increase in the education level of wage earners has taken place in urban China, as cohorts entering the labour force have been educated for longer than those exiting. Expressed as mean years of education, the increase was from 10.5 years in 1988 to 12.9 years in 2013. The increase between the same years in the proportion having a university degree was as rapid: from 7 to 21 per cent. Figure 6 shows that the relationship between education and average earnings was weak in 1988 but since then has become stronger and stronger. This also shows up in the larger and larger proportion of less-educated workers (primary school and below) having a relatively lower wage: a rapid increase from 19 per cent in 1988 to 56 per cent in 2007, with a marginal fall to 54 in 2013 (see Table A3). In contrast, the rate of workers earning a relatively low wage among those with a university education remained at 10 per cent or below during all years under study. 
Figure 6: Relative wages for workers with different length of education

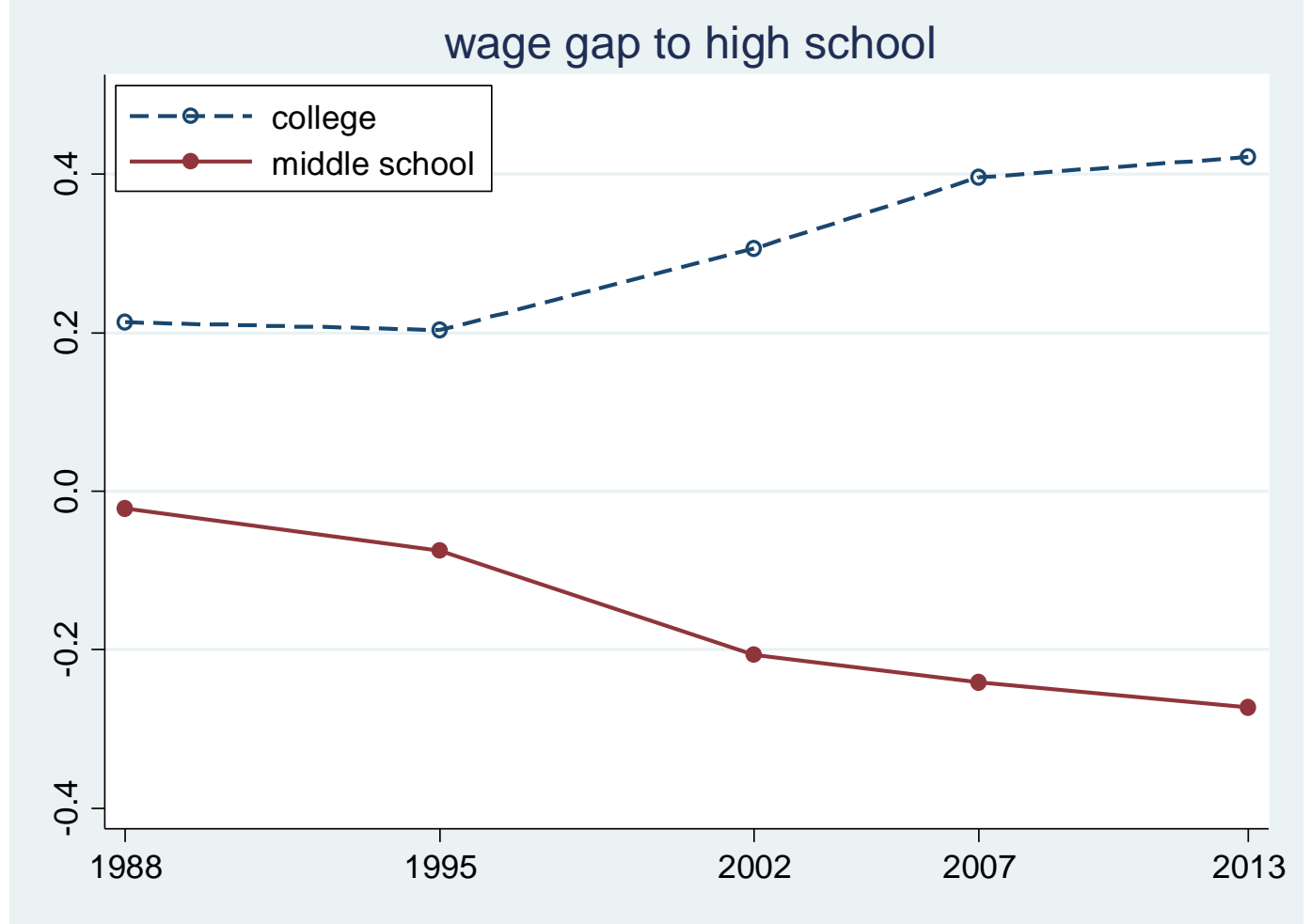

Note: The figure shows average wages compared with wages of workers with high-school education. Source: Authors' computations based on CHIP urban surveys.

Figure 7: Wages by gender and percentile

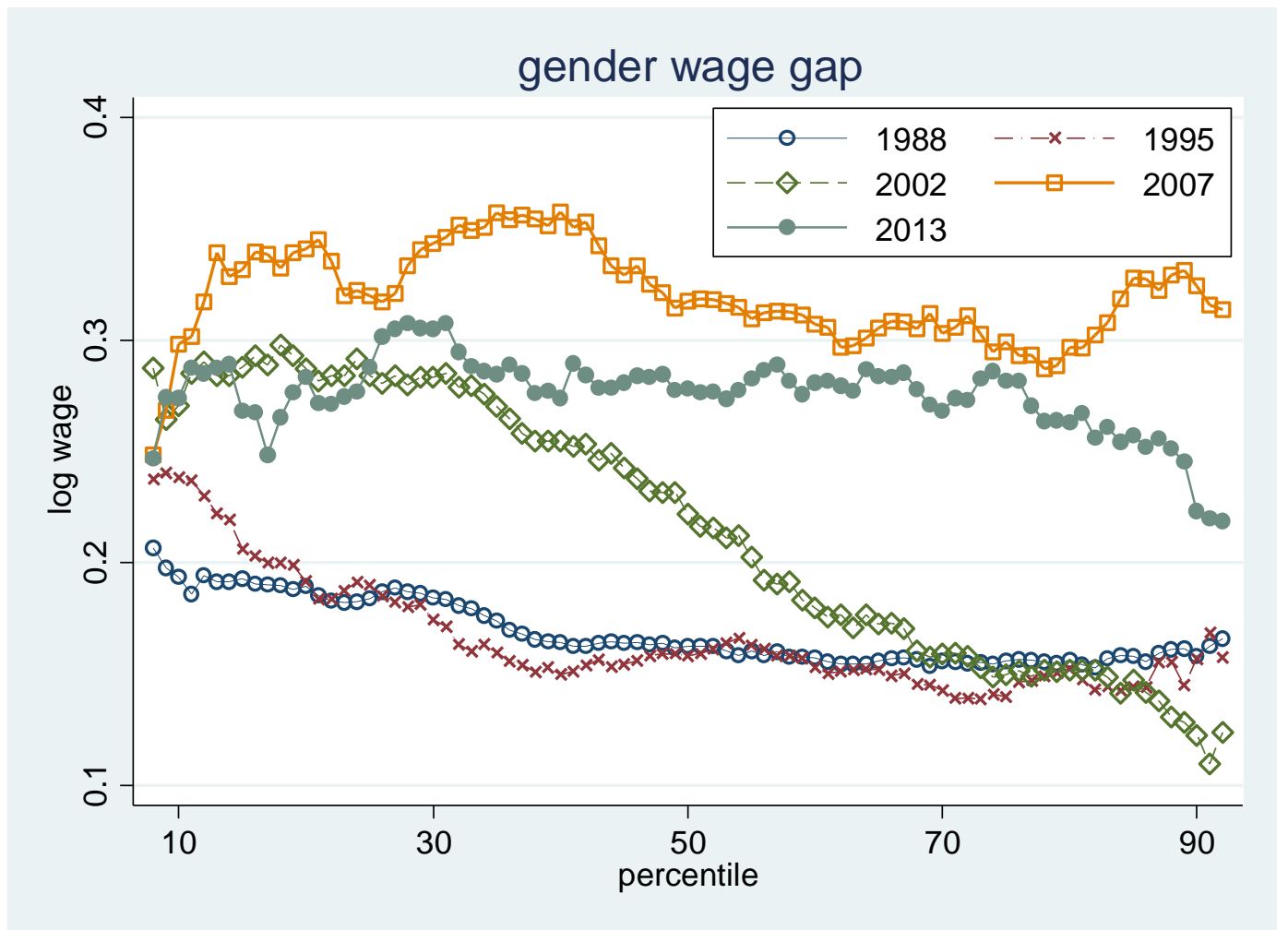

Source: Authors' computations based on CHIP urban surveys. 
Our data show an internationally observed small gender gap in employment rate in 1988, when 79 per cent of men were employed compared with 71 per cent of women (see Table A1). However, the gap increased from 8 per cent in 1988 to 17 per cent in 2013, as the employment rate among women decreased to 63 per cent while the rate among men remained more or less the same as in 1988. The fact that most people who had moved into self-employment were men is one of the reasons that the proportion of women among wage earners had not decreased more than from 48 per cent in 1988 to 43 per cent in $2013 .{ }^{10}$ Figure 7 illustrates that the gender wage gap, consistent with what has been reported in the literature, was small in 1988 as well as in 1995. However, after this, the gender wage gap widened, with this widening occurring first within the lower section of the wage distribution. This process had come to an end by 2007, after which the small change was in the opposite direction. The gender gap among low earners also increased, and in 2013 about 36 per cent of female workers were classified as earning low wages compared with 22 per cent of male workers.

Figure 8: Wages by ownership and percentile
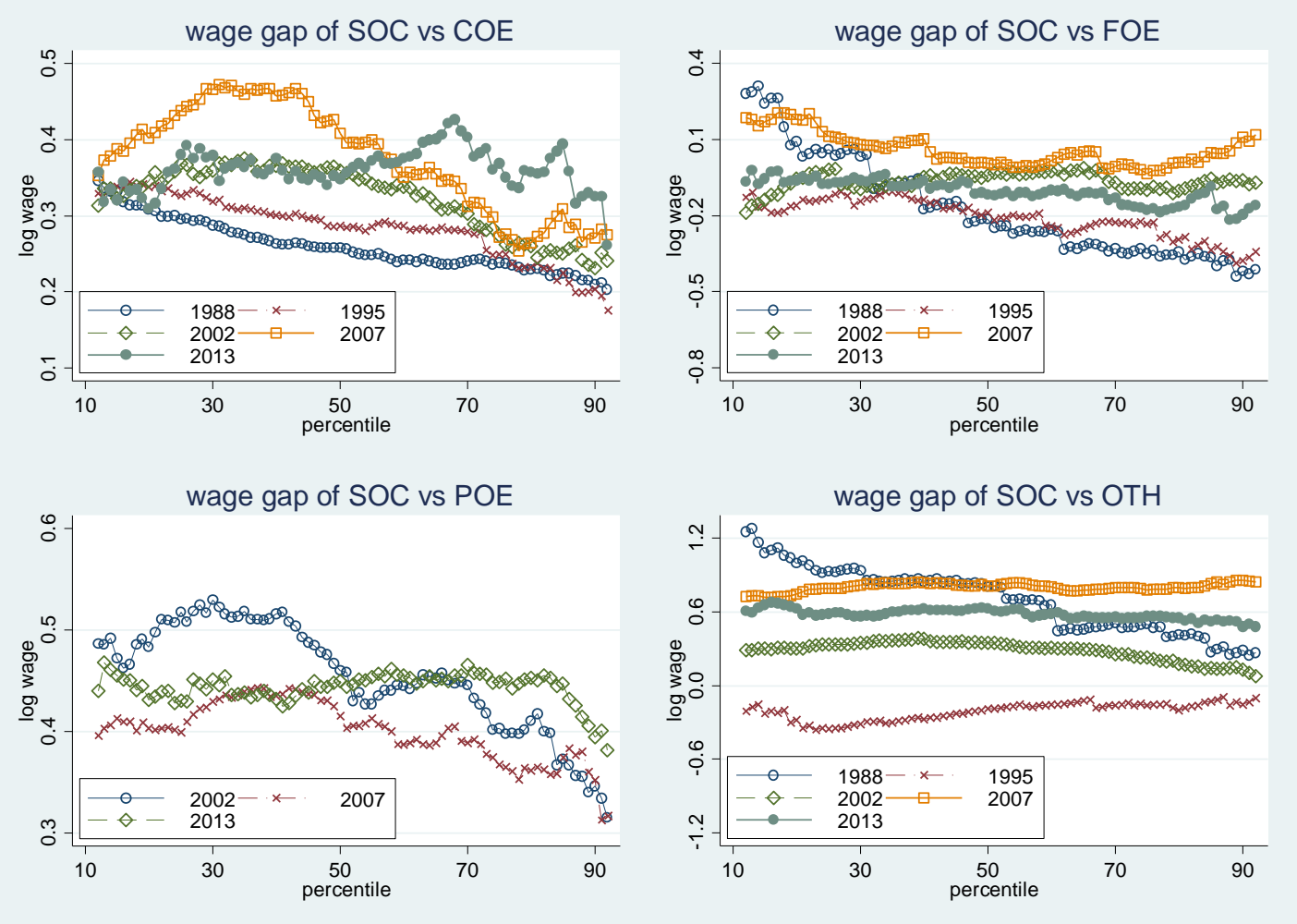

Notes: (1) 'SOC' indicates public work units (institutions, SOEs, and collectives), 'FOE' foreign-invested firms, 'POE' private-owned work units, and 'OTH' other work units; (2) due to rather small sample size do we not report results for the wage gap between public work units and private-owned work units for the years 1988 and 1995.

Source: Authors' computations based on CHIP urban surveys.

According to our data, almost all wage workers in 1988 and 1995 were employed in a state-owned work unit, a government institution, or a collective work unit. As is well known, this ownership composition changed radically thereafter and in 2013, 49 per cent were employed by the state and 36 per cent by private firms. In 2013, state-owned work units, together with the small number of foreign-owned firms, paid the highest average wages, while collective and private firms paid much

\footnotetext{
${ }^{10}$ For an analysis of gender differences in recruitment into self-employment in urban China based on the 1996 Life History and Social Change in Contemporary China Survey, see Zhang and Pan (2012).
} 
lower wages (see Figure 8). In 2013, as much as 39 per cent of workers in private work units earned low wages compared with not more than 16 per cent of those employed by the state. ${ }^{11}$

Figure 9: Wages by region and percentile
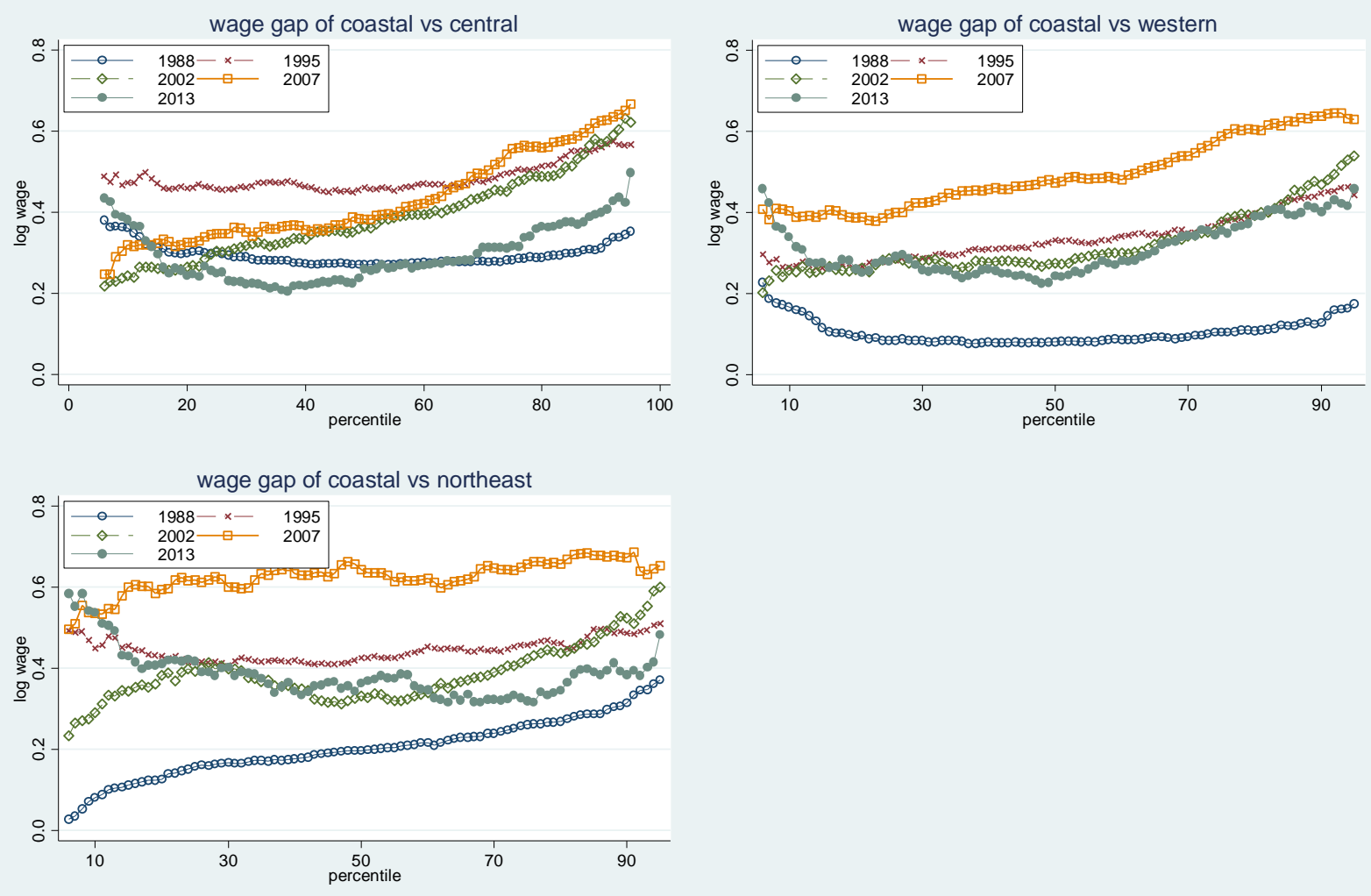

Source: Authors' computations based on CHIP urban surveys.

China first opened up to foreign trade and investments in the eastern coastal region of the country-one reason why mean wages are higher in this region than in the three other regions we have defined. Consistent with this, Figure 9 shows initially increased wage gaps between the coastal region and the other three regions, while the tendency is the opposite thereafter. In the same figure we find curves related to 1995 and later a tendency for regional gaps to be larger at the higher positions of the wage distribution. Thus, the regional wage differential increases by the position in the wage distribution. A possible reason is that workers in the eastern region differ from those in other regions in characteristics that are positively related to wages. In 2013, about 20 per cent of wage earners in the coastal region had a relatively low wage compared with as many as 38 per cent of workers in the northeastern region, with the corresponding proportions in the two other regions in a middle position.

\footnotetext{
${ }^{11}$ During the period studied here, the composition of wage earners in the production sector become more diverse. Table A2 shows that the proportion of workers employed in manufacturing decreased from 43 per cent in 1988 to no more than 18 per cent in 2013.
} 
Figure 10: Wages by ethnicity and percentile

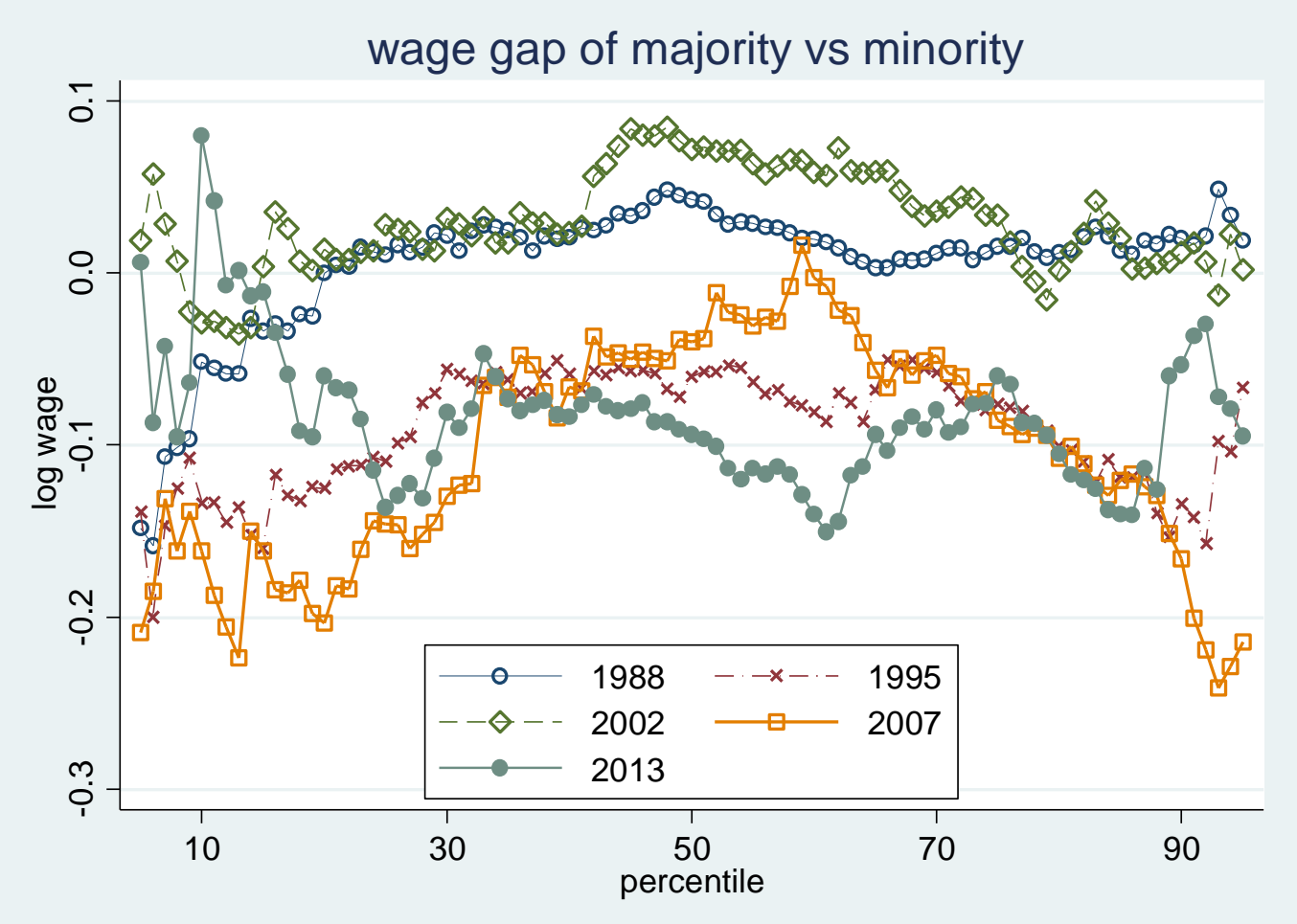

Source: Authors' computations based on CHIP urban surveys.

Figure 11: Wages by CPC membership and percentile

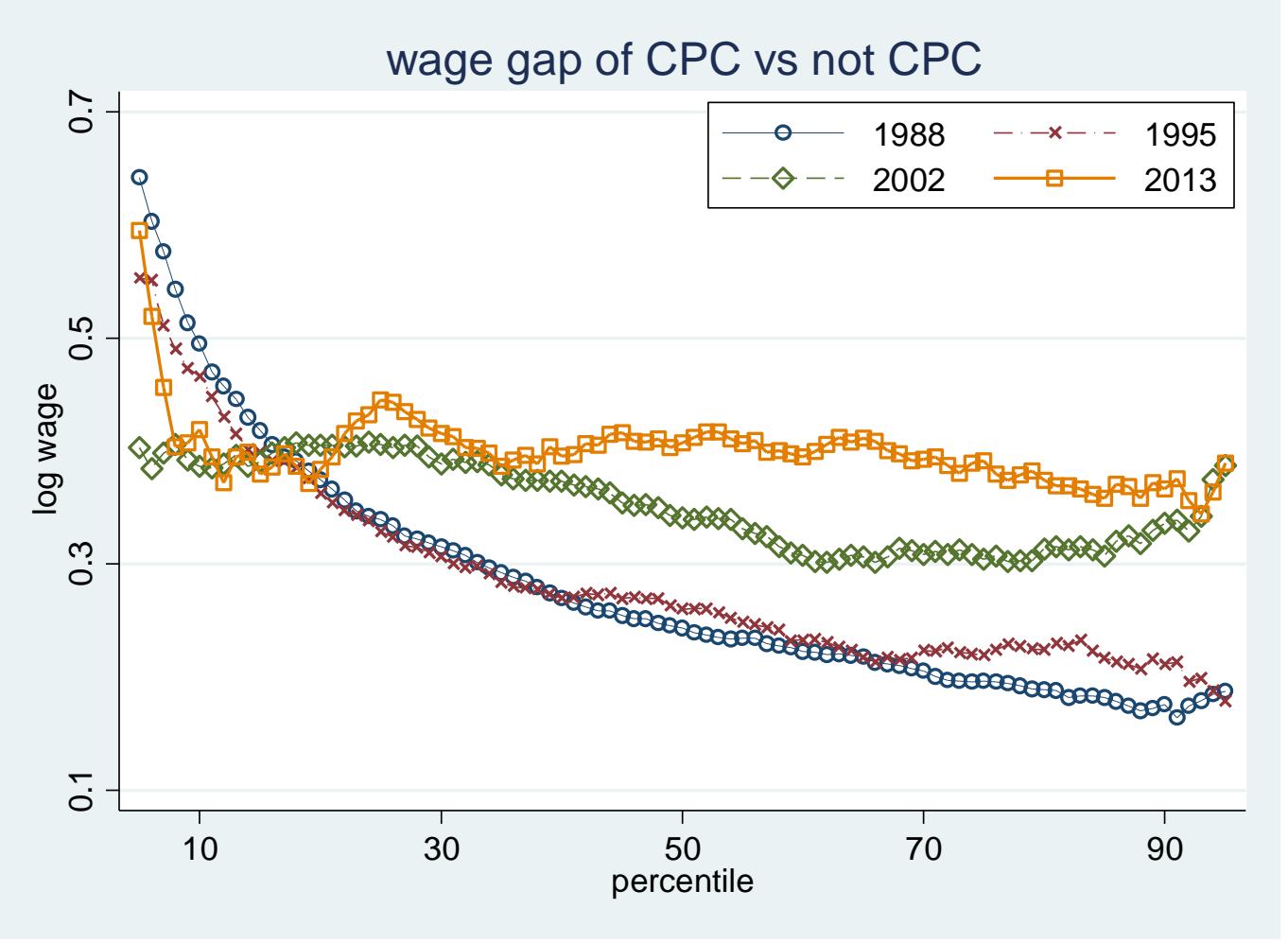

Note: The figure lacks data for 2007 as the CPC membership variable is missing in the 2007 survey. Source: Authors' computations based on CHIP urban surveys. 
No more than 3 to 4 per cent of workers in China belong to one of China's 55 ethnic minorities according to our data. This should be understood from the fact that still today, most minority people live in rural areas, while this is not the case for Han people. Figure 10 show a tendency for ethnic minority workers to earn lower wages compared with ethnic majority workers. While ethnic minority workers make up a rather small proportion of all wage earners, a considerably larger proportion are members of the CPC-about one in four or one in five. As shown in Figure 11, CPC party members have higher wages on average than non-members. Over the upper twothirds of the wage distribution there is a tendency for the disparity to increase over the years. In 2013, the incidence of low pay was 16 per cent among CPC party members compared with 31 per cent among workers who were not party members.

\section{$6 \quad$ Wage functions}

In order to better understand wage determination in urban China we have estimated wage functions separately for each of the five years under study. Two specifications were applied, both having log wages as the dependent variable. The first is of the Mincer type and includes education measured in number of years of schooling, years of experience, and years of experience squared. The variable 'years of experience' is calculated for each worker from information on age and years of schooling. This specification also includes dummies for male gender, for being married, for belonging to one of the ethnic minorities, and for being a CPC member. We also include two city-level variables. One is the logarithm of 'average wage of employed person in urban units', expecting a positive relationship, and the other is 'percentage of migrant workers in the city', expecting a negative coefficient. Information for these two variables was obtained from various years of the 'China City Statistical Yearbook' (National Bureau of Statistics 2018). Furthermore, we include province dummies as control variables. In the second specification we also add five dummies for occupation, four dummies for ownership, and fourteen dummies for industry. The estimates are reported in Table 4 and Table 5.

A first comment is that the relationship between wages and experience has changed profoundly between the survey for 1995 and the one for 2002, which is consistent with what the descriptive results reported in the previous section show. For example, the estimates reported in Table 4 show that in 1995, wages continued to increase by age up to 38 years of experience, which is for many workers close to the statutory retirement age. However, in 2002 the maximum was reached after 28 years, ten years earlier. A second comment is that the association between length of education and wages increased up until 2007. For example, in the first specification the coefficient increased from 0.036 in 1988 to 0.102 in 2007 - a rather large increase. Thereafter the coefficient decreased to 0.068 in 2013. In the second specification the coefficient for length of schooling is unsurprisingly somewhat lower, but the temporal pattern is very similar.

A third comment is that the coefficient for male gender has evolved as seen in other studies, which means a rapid increase from 1995 to 2007, while changes before and after those years were small. Also, for this variable the coefficients in the second specification are somewhat lower than those in the first specification. As reported in the literature, there is a positive coefficient for being a member of the CPC and the coefficients are lowest in 1988. There is little evidence of ethnic minority status being associated with earnings. The only signs are in the sample for 1995, when the negative coefficient is statistically significant at the 10 per cent but not at the 5 per cent level. Not surprisingly, we report that individual wages are positively related to the average city social wage in all samples. The variable measuring the proportion of migrants within the city is negatively related to the individual wage; this is statistically significant in one case in the first specification (1995) and in several cases in the second specification $(1995,2002$, and 2007). 
Table 4: Estimates of Mincer-type equation using OLS (Specification 1)

\begin{tabular}{|c|c|c|c|c|c|}
\hline Variables & 1988 & 1995 & 2002 & 2007 & 2013 \\
\hline \multirow[t]{2}{*}{ Male } & $0.105^{\star \star \star}$ & $0.116^{\star \star \star}$ & $0.185^{\star \star \star}$ & $0.307^{\star \star *}$ & $0.278^{\star \star \star}$ \\
\hline & $(0.006)$ & $(0.009)$ & $(0.012)$ & $(0.011)$ & $(0.018)$ \\
\hline \multirow[t]{2}{*}{ Schooling_years } & $0.036^{\star \star *}$ & $0.039 * \star *$ & $0.064^{\star \star *}$ & $0.102^{* * *}$ & $0.068^{* * *}$ \\
\hline & $(0.001)$ & $(0.002)$ & $(0.003)$ & $(0.002)$ & $(0.004)$ \\
\hline \multirow[t]{2}{*}{ Experience } & $0.048^{\star \star \star}$ & $0.030^{\star \star \star}$ & $0.033^{\star \star *}$ & $0.032^{\star \star *}$ & $0.049 * \star \star$ \\
\hline & $(0.001)$ & $(0.002)$ & $(0.003)$ & $(0.003)$ & $(0.003)$ \\
\hline \multirow[t]{2}{*}{ Experience_square/100 } & $-0.066^{\star \star \star}$ & $-0.040^{\star \star *}$ & $-0.059 * \star \star$ & $-0.057^{* \star *}$ & $-0.097^{* * *}$ \\
\hline & $(0.002)$ & $(0.004)$ & $(0.006)$ & $(0.005)$ & $(0.006)$ \\
\hline \multirow[t]{2}{*}{ Married } & & $0.173^{\star \star \star}$ & $0.186^{\star \star \star}$ & $0.179 * * *$ & $0.132^{\star \star \star}$ \\
\hline & & $(0.019)$ & $(0.025)$ & $(0.022)$ & $(0.030)$ \\
\hline \multirow[t]{2}{*}{ Ethnic_minority } & -0.019 & $-0.045^{\star}$ & 0.037 & -0.035 & 0.014 \\
\hline & $(0.014)$ & $(0.026)$ & $(0.036)$ & $(0.037)$ & $(0.049)$ \\
\hline \multirow[t]{2}{*}{ CPC_member } & $0.090 * \star \star$ & $0.123^{\star \star \star}$ & $0.193^{\star \star \star}$ & & $0.160^{\star \star \star}$ \\
\hline & $(0.008)$ & $(0.011)$ & $(0.014)$ & & $(0.023)$ \\
\hline \multirow[t]{2}{*}{ Social_wage_city } & $1.028^{\star \star \star}$ & $0.725^{\star \star \star}$ & $0.903^{\star \star \star}$ & $0.885^{\star \star \star}$ & $0.788^{\star \star \star *}$ \\
\hline & $(0.034)$ & $(0.033)$ & $(0.040)$ & $(0.033)$ & $(0.038)$ \\
\hline \multirow[t]{2}{*}{ Migrant_rate_city } & 0.000 & $-0.003^{\star \star \star}$ & -0.000 & -0.001 & 0.001 \\
\hline & $(0.001)$ & $(0.001)$ & $(0.001)$ & $(0.001)$ & $(0.001)$ \\
\hline \multirow[t]{2}{*}{ Constant } & $-1.434^{\star \star \star}$ & $1.356^{\star \star \star}$ & $-0.731^{*}$ & $-1.057^{\star \star \star}$ & 0.316 \\
\hline & $(0.297)$ & $(0.315)$ & $(0.401)$ & $(0.353)$ & $(0.420)$ \\
\hline Observations & 17,343 & 10,279 & 9,189 & 10,702 & 6,657 \\
\hline R-squared & 0.402 & 0.393 & 0.317 & 0.359 & 0.274 \\
\hline
\end{tabular}

Notes: (1) Wage is shown in log form, deflated to the year 2013; (2) apart from the variables above, the province dummies are included; (3) the dependent variable is the log wage; (4) standard errors in parentheses; (5) ${ }^{* * *} \mathrm{p}<0.01,{ }^{* *} \mathrm{p}<0.05,{ }^{*} \mathrm{p}<0.1 ;(6)$ the marital status variable in 1988 and CPC membership variable in 2007 were not included in the survey.

Source: Authors' estimates based on CHIP urban surveys.

Some comments can be made on characteristics that enter only the second specification. Not surprisingly, we find (when 'managers' is the omitted category) negative coefficients for the categories 'skilled worker', 'unskilled worker', and 'other occupation', for all years. When it comes to ownership of work unit, the estimates indicate a pattern which is broadly consistent with what earlier studies have shown. At the top are foreign-owned enterprises (1995 and 2002) and the state sector (2007). Finally, looking at the production sector, there is no example of a coefficient being statistically significant in all samples. 
Table 5: Estimates of Mincer-type equation using OLS (Specification 2)

\begin{tabular}{|c|c|c|c|c|c|}
\hline Variables & 1988 & 1995 & 2002 & 2007 & 2013 \\
\hline Male & $\begin{array}{r}0.087^{\star * *} \\
(0.006)\end{array}$ & $\begin{array}{r}0.098^{\star \star \star} \\
(0.009)\end{array}$ & $\begin{array}{r}0.142^{\star \star \star} \\
(0.012)\end{array}$ & $\begin{array}{c}0.226^{\star \star \star} \\
(0.011)\end{array}$ & $\begin{array}{r}0.237^{\star * *} \\
(0.019)\end{array}$ \\
\hline Schooling_years & $\begin{array}{r}0.021^{* * *} \\
(0.002)\end{array}$ & $\begin{array}{r}0.021^{\star \star *} \\
(0.002)\end{array}$ & $\begin{array}{r}0.028^{* * *} \\
(0.003)\end{array}$ & $\begin{array}{r}0.067^{\star * *} \\
(0.003)\end{array}$ & $\begin{array}{r}0.044^{* * *} \\
(0.004)\end{array}$ \\
\hline Experience & $\begin{array}{r}0.046^{\star * *} \\
(0.001)\end{array}$ & $\begin{array}{r}0.031^{\star \star \star} \\
(0.002)\end{array}$ & $\begin{array}{r}0.035^{\star * *} \\
(0.003)\end{array}$ & $\begin{array}{c}0.029 \star \star \star \\
(0.002)\end{array}$ & $\begin{array}{r}0.047^{\star \star \star} \\
(0.003)\end{array}$ \\
\hline Experience_square/100 & $\begin{array}{r}-0.065^{\star \star \star} \\
(0.002)\end{array}$ & $\begin{array}{r}-0.046^{\star \star \star} \\
(0.004)\end{array}$ & $\begin{array}{r}-0.069 * * \star \\
(0.005)\end{array}$ & $\begin{array}{r}-0.051^{\star * *} \\
(0.005)\end{array}$ & $\begin{array}{r}-0.096 \text { *** } \\
(0.006)\end{array}$ \\
\hline Married & & $\begin{array}{r}0.177^{\star * *} \\
(0.019)\end{array}$ & $\begin{array}{c}0.161^{\star * *} \\
(0.023)\end{array}$ & $\begin{array}{c}0.143^{\star \star \star} \\
(0.021)\end{array}$ & $\begin{array}{r}0.115^{\star \star \star} \\
(0.029)\end{array}$ \\
\hline Ethnic_minority & $\begin{array}{l}-0.013 \\
(0.014)\end{array}$ & $\begin{array}{c}-0.048^{\star} \\
(0.025)\end{array}$ & $\begin{array}{r}0.025 \\
(0.034)\end{array}$ & $\begin{array}{l}-0.026 \\
(0.034)\end{array}$ & $\begin{array}{r}0.011 \\
(0.048)\end{array}$ \\
\hline CPC_member & $\begin{array}{r}0.060 * * * \\
(0.008)\end{array}$ & $\begin{array}{r}0.084^{\star * *} \\
(0.012)\end{array}$ & $\begin{array}{r}0.109 * * * \\
(0.014)\end{array}$ & & $\begin{array}{r}0.109 * \star \star \\
(0.024)\end{array}$ \\
\hline Professional & $\begin{array}{r}-0.024^{*} \\
(0.014)\end{array}$ & $\begin{array}{r}0.011 \\
(0.017)\end{array}$ & $\begin{array}{r}-0.068^{\star * \star} \\
(0.022)\end{array}$ & $\begin{array}{l}-0.026 \\
(0.027)\end{array}$ & $\begin{array}{l}0.077^{*} \\
(0.042)\end{array}$ \\
\hline Clerk & $\begin{array}{r}-0.043^{\star * *} \\
(0.013)\end{array}$ & $\begin{array}{r}-0.071^{\star \star *} \\
(0.017)\end{array}$ & $\begin{array}{r}-0.170 \text { *** } \\
(0.021)\end{array}$ & $\begin{array}{r}-0.137^{\star \star *} \\
(0.025)\end{array}$ & $\begin{array}{l}-0.034 \\
(0.040)\end{array}$ \\
\hline Skilled worker & $\begin{array}{r}-0.088^{\star \star \star} \\
(0.015)\end{array}$ & $\begin{array}{r}-0.077^{\star \star \star} \\
(0.019)\end{array}$ & $\begin{array}{r}-0.177^{\star * *} \\
(0.024)\end{array}$ & $\begin{array}{r}-0.228^{\star \star \star} \\
(0.028)\end{array}$ & $\begin{array}{r}-0.114^{\star \star *} \\
(0.043)\end{array}$ \\
\hline Not-skilled worker & $\begin{array}{r}-0.154^{\star \star \star} \\
(0.018)\end{array}$ & $\begin{array}{r}-0.175^{\star \star \star} \\
(0.020)\end{array}$ & $\begin{array}{r}-0.387^{\star \star *} \\
(0.024)\end{array}$ & $\begin{array}{r}-0.292^{\star \star *} \\
(0.030)\end{array}$ & $\begin{array}{r}-0.120 \text { *** } \\
(0.041)\end{array}$ \\
\hline Others & $\begin{array}{r}-0.111^{\star \star \star} \\
(0.014)\end{array}$ & $\begin{array}{r}-0.148 * \star \star \\
(0.026)\end{array}$ & $\begin{array}{r}-0.452^{\star \star *} \\
(0.043)\end{array}$ & $\begin{array}{r}-0.265^{\star \star \star} \\
(0.036)\end{array}$ & $\begin{array}{r}-0.122^{\star \star} \\
(0.052)\end{array}$ \\
\hline Collective owned & $\begin{array}{r}-0.170 * * * \\
(0.008)\end{array}$ & $\begin{array}{r}-0.186^{\star \star \star} \\
(0.013)\end{array}$ & $\begin{array}{r}-0.124^{\star \star *} \\
(0.019)\end{array}$ & $\begin{array}{r}-0.252^{\star \star *} \\
(0.020)\end{array}$ & $\begin{array}{r}-0.266^{\star \star \star} \\
(0.044)\end{array}$ \\
\hline Foreign owned & $\begin{array}{l}-0.054 \\
(0.046)\end{array}$ & $\begin{array}{r}0.173^{\star * *} \\
(0.035)\end{array}$ & $\begin{array}{r}0.131^{\star * *} \\
(0.037)\end{array}$ & $\begin{array}{r}-0.132^{\star \star *} \\
(0.033)\end{array}$ & $\begin{array}{c}0.085^{\star} \\
(0.050)\end{array}$ \\
\hline Private owned & $\begin{array}{r}-0.404^{\star \star \star} \\
(0.079)\end{array}$ & $\begin{array}{r}-0.179 * \star * \\
(0.048)\end{array}$ & $\begin{array}{r}-0.185^{\star \star \star} \\
(0.021)\end{array}$ & $\begin{array}{r}-0.203^{\star \star *} \\
(0.015)\end{array}$ & $\begin{array}{r}-0.220^{\star \star \star} \\
(0.025)\end{array}$ \\
\hline Others & $\begin{array}{r}-0.685^{\star \star \star} \\
(0.050)\end{array}$ & $\begin{array}{l}-0.001 \\
(0.043)\end{array}$ & $\begin{array}{r}-0.104^{\star \star *} \\
(0.019)\end{array}$ & $\begin{array}{r}-0.459^{* \star *} \\
(0.021)\end{array}$ & $\begin{array}{r}-0.272^{\star \star \star} \\
(0.038)\end{array}$ \\
\hline Mining & $\begin{array}{r}0.018 \\
(0.030)\end{array}$ & $\begin{array}{r}0.034 \\
(0.055)\end{array}$ & $\begin{array}{r}0.053 \\
(0.064)\end{array}$ & $\begin{array}{r}0.292^{\star \star \star} \\
(0.077)\end{array}$ & $\begin{array}{r}0.152 \\
(0.098)\end{array}$ \\
\hline Manufacturing & $\begin{array}{l}-0.014 \\
(0.027)\end{array}$ & $\begin{array}{l}-0.055 \\
(0.036)\end{array}$ & $\begin{array}{c}-0.088^{\star} \\
(0.052)\end{array}$ & $\begin{array}{r}0.047 \\
(0.058)\end{array}$ & $\begin{array}{r}0.070 \\
(0.084)\end{array}$ \\
\hline Construction & $\begin{array}{r}0.000 \\
(0.030)\end{array}$ & $\begin{array}{l}-0.046 \\
(0.043)\end{array}$ & $\begin{array}{l}-0.050 \\
(0.059)\end{array}$ & $\begin{array}{r}0.000 \\
(0.065)\end{array}$ & $\begin{array}{r}0.128 \\
(0.089)\end{array}$ \\
\hline Wholesale, retail, and restaurant trades & $\begin{array}{l}-0.019 \\
(0.027)\end{array}$ & $\begin{array}{r}-0.099 * \star * \\
(0.037)\end{array}$ & $\begin{array}{c}-0.104^{*} \\
(0.054)\end{array}$ & $\begin{array}{l}-0.039 \\
(0.059)\end{array}$ & $\begin{array}{l}-0.100 \\
(0.087)\end{array}$ \\
\hline Transportation, storage, post, and telecommunication & $\begin{array}{l}-0.003 \\
(0.028)\end{array}$ & $\begin{array}{r}0.015 \\
(0.040)\end{array}$ & $\begin{array}{r}0.071 \\
(0.054)\end{array}$ & $\begin{array}{r}0.092 \\
(0.060)\end{array}$ & $\begin{array}{r}0.095 \\
(0.088)\end{array}$ \\
\hline Finance and insurance & $\begin{array}{l}-0.013 \\
(0.035)\end{array}$ & $\begin{array}{r}0.202^{\star \star \star} \\
(0.047)\end{array}$ & $\begin{array}{r}0.085 \\
(0.060)\end{array}$ & $\begin{array}{c}0.235^{\star \star \star} \\
(0.064)\end{array}$ & $\begin{array}{c}0.166^{\star} \\
(0.097)\end{array}$ \\
\hline Real estate & $\begin{array}{r}-0.104^{\star * \star} \\
(0.034)\end{array}$ & $\begin{array}{l}-0.031 \\
(0.041)\end{array}$ & $\begin{array}{r}0.071 \\
(0.069)\end{array}$ & $\begin{array}{l}0.159 \star * \\
(0.068)\end{array}$ & $\begin{array}{r}0.079 \\
(0.114)\end{array}$ \\
\hline $\begin{array}{l}\text { Scientific research, professional, information, computer, } \\
\text { and technical services }\end{array}$ & $\begin{array}{l}-0.007 \\
(0.032)\end{array}$ & $\begin{array}{r}0.040 \\
(0.047)\end{array}$ & $\begin{array}{r}0.069 \\
(0.066)\end{array}$ & $\begin{array}{r}0.174^{\star * *} \\
(0.062)\end{array}$ & $\begin{array}{l}-0.014 \\
(0.093)\end{array}$ \\
\hline $\begin{array}{l}\text { Residential, leasing, and business services; water, } \\
\text { environment, and public facility services }\end{array}$ & $-0.194^{\star * \star}$ & 0.063 & $-0.226^{\star \star \star}$ & -0.048 & -0.085 \\
\hline
\end{tabular}




\begin{tabular}{lrrrrr}
\hline & $(0.040)$ & $(0.096)$ & $(0.054)$ & $(0.059)$ & $(0.085)$ \\
Education, culture, sports, and entertainment & $-0.051^{\star}$ & -0.016 & $0.167^{\star \star \star}$ & $0.105^{\star}$ & -0.047 \\
& $(0.029)$ & $(0.039)$ & $(0.054)$ & $(0.059)$ & $(0.088)$ \\
Health industries, social security, and social work & -0.025 & 0.004 & $0.184^{\star \star \star}$ & 0.054 & 0.003 \\
& $(0.030)$ & $(0.041)$ & $(0.056)$ & $(0.062)$ & $(0.093)$ \\
Public management, social organizations, and & $-0.064^{\star \star}$ & -0.021 & 0.087 & 0.081 & -0.000 \\
governments & & & & & \\
& $(0.028)$ & $(0.037)$ & $(0.053)$ & $(0.058)$ & $(0.087)$ \\
Others & $-0.226^{\star \star \star}$ & -0.078 & $0.102^{\star}$ & $0.209^{\star \star \star}$ & 0.140 \\
& $(0.042)$ & $(0.069)$ & $(0.056)$ & $(0.064)$ & $(0.096)$ \\
Social_wage_city & $1.034^{\star \star *}$ & $0.704^{\star \star \star}$ & $0.944^{\star \star \star}$ & $0.845^{\star \star \star}$ & $0.747^{\star * \star}$ \\
& $(0.034)$ & $(0.032)$ & $(0.037)$ & $(0.031)$ & $(0.037)$ \\
Migrant_rate_city & 0.002 & $-0.004^{\star \star \star}$ & $-0.001^{\star \star}$ & $-0.002^{\star \star \star}$ & 0.000 \\
& $(0.001)$ & $(0.001)$ & $(0.001)$ & $(0.001)$ & $(0.001)$ \\
Constant & $-1.149^{\star \star \star}$ & $1.889^{\star \star \star}$ & -0.365 & 0.124 & $1.316^{\star \star \star}$ \\
& $(0.294)$ & $(0.311)$ & $(0.378)$ & $(0.336)$ & $(0.425)$ \\
Observations & 17,274 & 10,279 & 9,189 & 10,702 & 6,657 \\
R-squared & 0.436 & 0.429 & 0.411 & 0.451 & 0.314 \\
\hline
\end{tabular}

Notes: (1) Wage is shown in log form, deflated to the year 2013; (2) apart from the variables above, the province dummies are also included; (3) the dependent variable is the log wage; (4) standard errors in parentheses; (5) *** $p<0.01,{ }^{* *} p<0.05,{ }^{*} p<0.1$; (6) marriage variable in 1988 and CPC membership variable in 2007 were not included in the survey; (7) the omitted occupation category is 'managers' and the omitted ownership category is 'state owned'.

Source: Authors' estimates based on CHIP urban surveys.

In Tables 6 and 7 we decompose wage inequality based on the two specifications of the wage function using the Shapley method. The tables show very clearly that in 1988 and 1995, most wage inequality could be attributed to experience. However, in 2002 the proportion explained by experience had decreased rather considerably. Thus, the decrease took place during the years of very extensive changes in the relationship between work units and worker, when employment rates decreased and unemployment surfaced. Opposing this, the proportion of wage inequality that can be attributed to education increased. According to the first specification, most wage inequality in 2002 and in each subsequent year can be attributed to education. The second specification tells a somewhat different story. It attributes less wage inequality to education and a substantial part, particularly in 2002, to occupation. However, thereafter the proportion of inequality that can be attributed to occupation is lower. This means that for example in 2013, 15 per cent of wage inequality can be attributed to occupation, compared with 14 per cent to ownership and 10 per cent to gender.

Table 6: Regression-based decomposition of log wage (percentage), Specification 1

\begin{tabular}{lrrrrr}
\hline & $\mathbf{1 9 8 8}$ & $\mathbf{1 9 9 5}$ & $\mathbf{2 0 0 2}$ & $\mathbf{2 0 0 7}$ & $\mathbf{2 0 1 3}$ \\
Gender & 9.63 & 12.54 & 11.53 & 19.12 & 12.11 \\
Education years & 18.17 & 33.40 & 68.57 & 64.47 & 64.23 \\
Experience & 45.09 & 32.41 & 12.50 & 5.98 & 7.64 \\
Experience & 26.42 & 20.54 & 7.16 & 4.99 & 6.02 \\
square/100 & & & & & \\
Ethnic status & 0.03 & 0.65 & 0.14 & 0.33 & 0.09 \\
Province & 0.66 & 0.46 & 0.11 & 5.10 & 9.91 \\
Total & 100.0 & 100.0 & 100.0 & 100.0 & 100.0 \\
\hline
\end{tabular}

Notes: (1) Wage is shown in log form, deflated to the year 2013; (2) all the figures are adjusted with weighting; (3) we use the Shapley decomposition method for the regression-based decomposition.

Source: Table 4 and authors' computations based on CHIP urban surveys. 
Table 7: Regression-based decomposition of log wage (percentage), Specification 2

\begin{tabular}{|c|c|c|c|c|c|}
\hline & 1988 & 1995 & 2002 & 2007 & 2013 \\
\hline Gender & 7.69 & 10.83 & 6.86 & 13.92 & 10.07 \\
\hline Education years & 9.79 & 21.81 & 27.86 & 36.56 & 41.50 \\
\hline Experience & 40.04 & 29.25 & 7.67 & 4.01 & 5.76 \\
\hline $\begin{array}{l}\text { Experience } \\
\text { square/100 }\end{array}$ & 23.13 & 18.45 & 4.48 & 3.31 & 4.48 \\
\hline Ethnic status & 0.03 & 0.61 & 0.06 & 0.28 & 0.10 \\
\hline Ownership & 7.58 & 0.69 & 5.39 & 14.41 & 13.65 \\
\hline Occupation & 10.39 & 15.84 & 39.80 & 20.53 & 14.85 \\
\hline Industry & 0.84 & 1.93 & 7.69 & 3.07 & 1.45 \\
\hline Province & 0.51 & 0.59 & 0.19 & 3.90 & 8.15 \\
\hline Total & 100.0 & 100.0 & 100.0 & 100.0 & 100.0 \\
\hline
\end{tabular}

Note: (1) Wage is shown in log form, deflated to the year 2013; (2) all the figures are adjusted with weighting; (3) we use the Shapley decomposition method for the regression-based decomposition.

Source: Table 5 and authors' computations based on CHIP urban surveys.

\section{$7 \quad$ Summary and discussion}

In this paper we have analysed the development of wages among urban residents in China during the period 1988-2013. At the start of this period workers were administratively allocated and typically had lifelong relationships with their work units, which were owned by the state that also provided social insurance benefits, housing at very low costs, and social services. Meanwhile, the employment rates were very high. By the end of the period a labour market had emerged; more and more people had become employed in the private sector or moved into self-employment. In addition, a larger proportion of people than at the beginning of the period studied were not employed. To a large extent, work units had moved away from their role of providing social insurance, housing, and social services. The average worker in 2013 had been educated for a considerably longer period than his or her counterpart in 1988. While very few people with rural hukou worked in urban China in 1988, later many moved, temporarily or permanently, to urban locations, typically finding jobs that were less qualified than those held by urban residents.

We have analysed microdata for the years 1988, 1995, 2002, 2007, and 2013, covering a period that is uniquely long for studies on wages in urban China. We have focused on workers with urban hukou, for whom we have reported changes in wage levels, wage inequality, and the incidence of low wages. It should be an important step in future studies of wage inequality in urban China to broaden the analysis to cover all workers who live in urban China independent of their hukou status. In this paper we have also disaggregated the population of wage earners along several dimensions, emphasizing age, education, gender, and ownership sector. We have also studied changes in the composition of the category of workers and in how wage levels and incidence of low wages have varied over the period.

A first final comment on our results is that average wage growth has, from an international perspective, been very impressive. Expressed in constant prices using the CPI, average wages were about ten times as high in 2013 as in 1988. Seen from the perspective of high-income countries' experiences during the Great Recession, the continued rapid growth in average wages in urban China between 2007 and 2013 is remarkable.

A second final comment is that wage inequality was on a trajectory of continuous increase for two decades, from 1988 to 2007. For example, the Gini coefficient for workers' wages went up from 
0.23 to 0.38 . The incidence of low wages (defined as those earning less than two-thirds of contemporary median earnings) increased from 17 per cent in 1988 to 27 per cent in 2002. However, the various inequality indices we reported for 2013 show no clear pattern of apparent increases in wage inequality since 2007.

Our third concluding comment is that during the planning period, the combination of wage scales favouring seniority and the very low mobility of labour led to a strong positive relationship between the age of the worker and their wages that continued throughout working life. However, this changed, and more recently the earnings of older workers have been (in cross-sections) lower than those of middle-aged workers. Compare the incidence of low wages for the youngest and the oldest during the first and last years under study: in 1988, 55 per cent of workers aged 16-25 were classified as earning a low wage but this applied to not more than 6 per cent among those aged 4655. The corresponding numbers in 2013 were 47 per cent and 41 per cent. Our regression-based decomposition analysis shows that in 1988 a majority of wage inequality could be attributed to differences in wages due to age. However, this proportion decreased rapidly between 1995 and 2002, during which period relations between work units and workers became fundamentally different, many workers left the labour force, and others became unemployed.

During the planned-economy period, the relationship between workers' length of education and wages was weak in urban China-much weaker than in high-income countries. Our fourth final comment is that our computations and estimates confirm that since China moved away from the administrative allocation of labour, the relationship between length of education and wages has become stronger. This is most probably due to several factors: changed wage-setting mechanisms, the rapidly increased demand for qualified labour, and a large inflow of relatively unqualified migrants. For example, in a Mincer-type equation (our Specification 1) the coefficient for years of education on ln wages increased from 0.036 in 1988 to 0.102 in 2007. However, parallel to what we have reported for wage inequality, the corresponding coefficient was lower in 2013. Such a levelling off is consistent with the rapid expansion of higher education that China has experienced, as well as the decreased inflow of relatively unqualified migrants. The regression-based decomposition of wage inequality shows that in 1988 the proportion of wage inequality attributable to education was much smaller than that attributable to experience. However, the roles changed, and education was the single largest contributor (of the much larger wage inequality) in 2013.

Our fifth concluding comment is that in 1988 urban China had an internationally low gender wage gap. However, the development thereafter was less favourable for women than for men. Female labour force participation has decreased, with a widening of the employment gap to men from 8 per cent in 1988 to 17 per cent in 2013. The gender wage gap increased from 1995 to 2007, during which time in a Mincer-type specification the dummy for being male on ln wages increased from 0.12 to 0.31 . In 2013 not less than 36 per cent of female workers were classified as having a low wage compared with 22 per cent of male workers. The decreased employment rates and the increased gender wage gap lead us to predict that power relations between Chinese spouses have changed since the mid-1990s so that, on average, the bargaining position of husbands has strengthened while that of wives has weakened.

A sixth conclusion is that over the period we studied, workers in foreign-owned enterprises, as well as those in the state sector, received a wage premium compared with workers in other ownership types. We have also documented other differences in wages. On average, wages in the eastern, coastal region of China are higher than those in other regions. Members of the Communist Party of China earn more than other workers, even after controlling for a number of characteristics. However, there is not much of a wage difference between the ethnic majority and the ethnic minorities taken as a single category. 
Much of what has been reported here is consistent with what has been reported in the now sizeable literature on wage inequality and wage determination in urban China that we surveyed in Section 2. What are new, according to our reading of the literature, are the findings we report for 2013. We actually found little change since 2007 in the average wage growth and in wage inequality, and also not much change in wage determination, between 2007 and 2013. This lack of significant change is in sharp contrast to the many major changes we reported for the previous subperiods, and is in one sense probably the single newest and most interesting result.

\section{References}

Appleton, S., J. Knight, L. Song, and Q. Xia (2005a). 'The Economics of Communist Party Membership: The Curious Case of Rising Numbers and Wage Premium during China's Transition', The Journal of Development Studies, 45(2): 256-75.

Appleton, S., L. Song, and Q. Xia (2005b). 'Has China Crossed the River? The Evolution of Wage Structure in Urban China during Reform and Retrenchment'. Journal of Comparative Economics, 33(4): 644-63.

Appleton, S., L. Song, and Q. Xia (2014). 'Understanding Urban Wage Inequality in China 19882008: Evidence from Quantile Analysis’. World Development, 62: 1-13.

Bargain, O., S.K. Bhaumik, M. Chakrabarty, and Z. Zhao (2009). 'Earnings Differences between Chinese and Indian Wage Earners, 1987-2004'. Review of Income and Wealth, 55(s1), 562-87.

Cai, L. and A. Liu (2015). 'Wage Determination and Distribution in Urban China and Vietnam: A Comparative Analysis'. Journal of Comparative Economics, 43: 186-203.

Bishop, J.A., F. Luo, and F. Wang (2005). 'Economic Transition, Gender Bias, and the Distribution of Earnings in China'. Economics of Transition, 13(2): 239-59.

Chen, Y., S. Démurger, and M. Fournier (2005). 'Earnings Differentials and Ownership Structure in Chinese Enterprises'. Economic Development and Cultural Change, 53(4): 933-58.

Chen, Z., Y. Ge, and H. Lai (2011). 'Foreign Direct Investment and Wage Inequality: Evidence from China'. World Development, 39(8): 1322-32.

Chi, W., and B. Li (2008). 'Glass Ceiling or Sticky Floor? Examining the Gender Earnings Differential across the Earnings Distribution in Urban China, 1987-2004'. Journal of Comparative Economics, 36(2): 243-63.

Chi, W., B. Li, and Q. Yu (2011). 'Decomposition of the Increase in Earnings Inequality in Urban China: A Distributional Approach'. China Economic Review, 22(3): 299-312.

Démurger, S., S. Li, and J. Jang (2012). 'Earnings Differentials between the Public and Private Sectors in China: Exploring Changes for Urban Local Residents in the 2000s'. China Economic Review, 23(1): 138-53.

Démurger, S. M. Gurgand, S. Li, and X. Yue (2009). 'Migrants as Second-Class Workers in Urban China? A Decomposition Analysis'. Journal of Contemporary China, 37(4): 610-28.

Démurger, S., M. Fournier, and Y. Chen (2007). 'The Evolution of Gender Earnings Gaps and Discrimination in Urban China, 1988-95'. The Developing Economics, 45(1): 97-121.

Démurger, S., M. Fournier, S. Li, and W. Zhong (2006). 'Economic Liberalization with Rising Segmentation in China's Urban Labor Market', Asian Economic Papers, 5(3): 58-101.

Deng, Q., and S. Li (2009). 'What Lies behind Rising Earnings Inequality in Urban China? Regression-Based Decompositions'. CESifo Economic Studies, 55(3-4): 598-623. 
Deng, Q., and S. Li (2012). 'Low-Paid Workers in Urban China'. International Labour Review, 151(3): 157-71.

Ding S. (2010). 'An Analysis of Minimum Wage Effects on the Labour Market-Effect of Interaction with the Law of the PRC on Employment Contracts'. Social Science in China, 1: 85102 (in Chinese).

Ding, S., S. Li, and S. Myers (2013). 'Intertemporal Changes in Ethnic Urban Earnings Disparities in China'. In S. Li, H. Sato, and T. Sicular (eds), Rising Inequality in China: Challenges to a Harmonious Society. Cambridge: Cambridge University Press.

Du., F., and X. Dong (2013). 'Women's Employment and Child Care Choices in Urban China during the Economic Transition'. Economic Development and Cultural Change, 62(1): 131-55.

Fleisher, B.M., K. Sabirianova, and X. Wang (2005). 'Returns to Skills and the Speed of Reforms: Evidence from Central and Eastern Europe, China, and Russia'. Journal of Comparative Economics, 33(2): 351-70.

Gao, W., and R. Smyth (2015). 'Education Expansion and Returns to Schooling in Urban China, 2001-2010: Evidence from Three Waves of the China Urban Labor Survey'. Journal of the Asia Pacific Economy, 20(2): 178-201.

Ge, S., and T. Yang (2014). 'Changes in China's Wage Structure'. Joumal of the European Economic Association, 12(2): 300-36.

Gustafsson, B., and S. Ding (2017). 'Unequal Growth: How Household Income and Poverty in Urban China Have Developed since 1988, with an Emphasis on the Period from 2007 to 2013'. Working Paper 2017-18. Ontario: Centre for Human Capital and Productivity (CHCP), Department of Economics, Social Science Centre, Western University.

Gustafsson, B., and S. Li (2000). 'Economic Transformation and the Gender Earnings Gap in Urban China'. Journal of Population Economics, 13(2): 305-29.

Gustafsson, B., and S. Li (2001). 'The Anatomy of Rising Earnings Inequality in Urban China'. Journal of Comparative Economics, 29(1): 118-35.

Gustafsson, B., and X. Yang (2017). 'Earnings among Nine Ethnic Minorities and the Han Majority in China's Cities'. Journal of the Asia Pacific Economy, 22(3): 524-43.

Gustafsson, B., S. Li, L. Nivorozhkina, and H. Wan (2015). 'Yuan and Roubles: Comparing Wage Determination in Urban China and Russia at the Beginning of the New Millennium'. China Economic Review, 35: 248-65.

Gustafsson, B., S. Li, L. Nivorozhkina, and K. Katz (2001). 'Rubles and Yuan: Wage Functions for Russia and China'. Economic Development and Cultural Change, 50(1): 1-18.

Han, J., R. Liu, and J. Zhang (2012). 'Globalization and Wage Inequality: Evidence from Urban China', Journal of International Economics, 87(2): 288-97.

Hare, D. (2016). 'What Accounts for the Decline in Labor Force Participation among Married Women in Urban China, 1991-2011'. China Economic Review, 28: 251-66.

Hauser, S., and Y. Xie (2005). 'Temporal and Regional Variation in Earnings Inequality: Urban China in Transition between 1988 and 1995'. Social Science Research, 34(1): 44-79.

Johnson, E., and G. Chow (1997). 'Rates of Return to Schooling in China'. Pacific Economic Review, 2(2): 101-13.

Knight, J., and L. Song (2003). 'Increasing Urban Wage Inequality in China. Extent, Elements and Evaluation', Economics of Transition, 11(4): 597-619. 
Knight, J., and L. Song (2008). 'China's Emerging Urban Wage Structure, 1995-2002'. In B. Gustafsson, S. Li, and T. Sicular (eds), Inequality and Public Policy in China. Cambridge: Cambridge University Press.

Knight, J., and L. Song (1993). 'Why Urban Wages Differ in China'. In K. Griffin and R. Zhao (eds), The Distribution of Income in China. Houndmills, Basingstoke: Macmillan.

Lee, J.-W., and D. Wie (2017). 'Wage Structure and Gender Earnings Differentials in China and India', World Development, 97: 313-29.

Li, H., P.W. Liu, J. Zhang, and N. Ma (2007). 'Economic Returns to Communist Party Membership: Evidence from Urban Chinese Twins'. Economic Journal, 117: 1504-20.

Li, S., and B. Gustafsson (2008). 'Unemployment. Early Retirement, and Changes in the Gender Income Gap in China 1995-2002. In B. Gustafsson, S. Li, and T. Sicular (eds), Inequality and Public Policy in China. Cambridge: Cambridge University Press.

Li, S., and J. Song (2013). 'Changes in the Gender-Wage Gap in Urban China, 1995-2007. In S. Li, H. Sato, and T. Sicular (eds), Rising Inequality in China. Challenges to a Harmonious Society. Cambridge: Cambridge University Press.

Lin, C., and M.-S. Yun (2016). 'The Effects of the Minimum Wage on Earnings Inequality: Evidence from China'. In L. Cappellari, S. Polchek, and K. Tatsiramos (eds), Income Inequality around the World. Research in Labor Economics, 44. Bingley, West Yorkshire: Emerald Publishing Group Limited.

Liu, H. (2011). 'Economic Reforms and Gender Inequality in Urban China'. Economic Development and Cultural Change, 59(4): 839-76.

Liu, Z. (1998). 'Earnings, Education, and Economic Reforms in Urban China'. Economic Development and Cultural Change, 46(4): 697-725.

Ma, X. (2018). 'Labor Market Segmentation by Industry Sectors and Wage Gaps between Migrants and Local Urban Residents in Urban China'. China Economic Review, 47: 96-115.

Maurer-Fazio, M. (1999). 'Earnings and Education in China's Transition to a Market Economy Survey Evidence from 1989 and 1992'. China Economic Review, 10(1): 17-40.

Meng, X., K. Shen, and S. Xue (2013). 'Economic Reform, Education Expansion, and Earnings Inequality for Urban Males in China, 1988-2009'. Journal of Comparative Economics, 41(1): 22744.

Meng, X. (2012). 'Labor Market Outcomes and Reforms in China'. Journal of Economic Perspectives, 26(4): 75-102.

MHRSS (Ministry of Human Resource and Social Security) (2016). Policy Documents Related to Minimum Wage. Available at: http://www.mohrss.gov.cn/SYrlzyhshbzb/ gongzishourufenpei/zcwj/zuidigongzi/ (accessed 18 August 2018).

National Bureau of Statistics (2018). 'China City Statistical Yearbook'. China Statistical Press, July: 92-105.

Ng, Y.C. (2007). 'Gender Earnings Differentials and Regional Economic Development in Urban China, 1988-97'. Review of Income and Wealth, 53(1): 148-66.

Qu, Z., and Z. Zhao (2017). 'Glass Ceiling Effect in Urban China: Wage Inequality of Rural-Urban Migrants during 2002-2007. China Economic Review, 42: 118-44.

Ravallion, M., and S. Chen (2003). 'Measuring Pro-Poor Growth'. Economic Letters, 78(1): 93-99. 
Shu, X., and Y. Bian (2003). 'Market Transition and Gender Gap in Earnings in Urban China'. Social Forces, 81(4): 1107-45.

Song, J., T. Sicular, and B. Gustafsson (2017). 'China's Urban Gender Gap: A New Direction?' Working Paper 2017-23. Ontario: Centre for Human Capital and Productivity (CHCP), Department of Economics, Social Science Centre, Western University.

Wang, L. (2012). 'Economic Transition and College Premium in Urban China'. China Economic Review, 23: 1069-99.

Wang, L. (2013). 'How Does Education Affect the Earnings Distribution?' Oxford Bulletin of Economics and Statistics, 75(3): 435-54.

Whalley, J., and C. Xing (2016). 'Ownership Restructuring and Wage Inequality in Urban China'. International Labour Review, 155(1): 57-72.

Wu, X., and Y. Xie (2003). 'Does the Market Pay Off? Earnings Returns to Education in Urban China'. American Sociological Review, 68(3): 425-42

Wu, X. (2010). 'Voluntary and Involuntary Job Mobility and Earnings Inequality in Urban China, 1993-2000'. Social Science Research, 39(3): 382-95.

Wu, X. (2002). 'Work Units and Income Inequality: The Effect of Market Transition in Urban China'. Social Forces, 80(3): 1069-99.

Xie, Y., and X. Wu (2008). 'Danwei Profitability and Earnings Inequality in Urban China'. China Quarterly, 195: 558-81.

Xie, Y., and E. Hannum (1996). 'Regional Variation in Earnings Inequality in Reform-Era Urban China'. American Journal of Sociology, 101(4): 950-92.

Xing, C., and S. Li (2012). 'Residual Wage Inequality in Urban China, 1995-2007'. China Economic Review, 23(2): 205-22.

Xu, W., K.-C. Tan, and G. Wang (2006). 'Segmented Local Labor Markets in Postreform China: Gender Earnings Inequality in the Case of Two Towns in Zhejiang Province'. Environment and Planning A, 38(1): 85-109.

Yang, D.T. (2005). 'Determinants of Schooling Returns during Transition: Evidence from Chinese Cities'. Journal of Comparative Economics, 33(2): 244-64.

Yang, S., and S. Li (2017). 'International Financial Crisis and Wage Inequality in Urban China'. Economic and Political Studies, 5(3): 342-57.

Zhang, Q.F., and Z. Pan (2012). 'Women's Entry into Self-Employment in Urban China: The Role of Family in Creating Gendered Mobility Patterns'. World Development, 40(6): 1201-12.

Zhang, Y., and E. Hannum (2015). 'Diverging Fortunes: The Evolution of Gender Wage Gaps for Singles, Couples, and Parents in China, 1989-2009’. Chinese Journal of Sociology, 1(1): 15-55.

Zhang, Y., J. Han, P.-W. Liu, and Y. Zhao (2008a). 'Trends in the Gender Earnings Differential in Urban China, 1988-2004'. Industrial and Labor Relations Review, 61(2): 224-43.

Zhang, Y., E. Hannum, and M. Wang (2008b). 'Gender-Based Employment and Income Differences in Urban China: Considering the Contributions of Marriage and Parenthood'. Social Forces, 86(4): 1529-60.

Zhang, Y., Y. Zhao, A. Park, and S. Song (2005). 'Economic Returns to Schooling in Urban China, 1988 to 2001'. Journal of Comparative Economics, 33(4): 730-52.

Zhang, Z., and X. Wu (2017). 'Occupational Segregation and Earnings Inequality: Rural Migrants and Local Workers in Urban China'. Social Science Research, 61: 57-74. 
Zhao, Y. (2002). Earnings Differentials between State and Non-State Enterprises in Urban China'. Pacific Economic Review, 7(1): 181-97.

Zhou, X., (2014). 'Increasing Returns to Education, Changing Labor Force Structure, and the Rise of Earnings Inequality in Urban China, 1996-2010'. Social Forces, 93(2): 429-45.

Zhu, R. (2016). 'Wage Differentials between Urban Residents and Rural Migrants in Urban China during 2002-2007: A Distributional Analysis'. China Economic Review, 37: 2-14. 


\section{Appendix}

Table A1: Employment rate: (wage earner + self-employed)/ population (\%)

\begin{tabular}{|c|c|c|c|c|c|c|}
\hline & & 1988 & 1995 & 2002 & 2007 & 2013 \\
\hline \multirow[t]{5}{*}{ Age } & $16-25$ & 51.9 & 46.6 & 28.0 & 26.8 & 46.5 \\
\hline & $26-35$ & 97.9 & 94.8 & 89.1 & 89.3 & 87.8 \\
\hline & $36-45$ & 97.4 & 96.9 & 91.8 & 93.2 & 89.7 \\
\hline & $46-55$ & 78.3 & 77.7 & 79.8 & 77.5 & 81.5 \\
\hline & $56+$ & 25.5 & 20.4 & 30.5 & 31.3 & 52.3 \\
\hline \multirow[t]{2}{*}{ Gender } & Female & 70.6 & 67.5 & 63.1 & 61.2 & 63.2 \\
\hline & Male & 78.7 & 76.0 & 76.0 & 75.6 & 79.6 \\
\hline \multirow[t]{5}{*}{ Education } & Primary or lower & 57.4 & 37.1 & 34.3 & 31.2 & 66.5 \\
\hline & Junior middle & 89.4 & 74.2 & 67.0 & 58.9 & 76.8 \\
\hline & Senior middle & 92.8 & 73.6 & 71.3 & 67.9 & 66.6 \\
\hline & Technical & 94.5 & 87.0 & 84.4 & 84.1 & 74.6 \\
\hline & University or higher & 92.4 & 78.4 & 71.9 & 78.4 & 70.4 \\
\hline \multirow[t]{2}{*}{ Marital status } & Single or divorced & & 46.0 & 40.9 & 47.5 & 52.8 \\
\hline & Married & 74.6 & 78.1 & 77.5 & 75.3 & 76.9 \\
\hline \multirow[t]{2}{*}{ Ethnic status } & Majority & 74.7 & 71.8 & 69.5 & 68.3 & 71.5 \\
\hline & Minority & 72.9 & 69.9 & 67.9 & 63.9 & 73.1 \\
\hline \multirow[t]{2}{*}{ CPC membership } & No & 71.1 & 69.9 & 66.0 & & 70.9 \\
\hline & Yes & 88.4 & 78.1 & 80.7 & 68.2 & 78.7 \\
\hline \multirow[t]{4}{*}{ Region } & Coastal & 73.4 & 70.7 & 70.4 & 71.3 & 72.4 \\
\hline & Central & 75.5 & 69.5 & 68.7 & 67.7 & 71.9 \\
\hline & Western & 72.0 & 75.2 & 67.9 & 67.7 & 71.2 \\
\hline & Northeastern & 80.1 & 73.3 & 72.0 & 60.5 & 65.9 \\
\hline Overall & Total & 74.6 & 71.7 & 69.5 & 68.2 & 71.6 \\
\hline
\end{tabular}

Notes: (1) The variable 'marital status' is not available in the survey for 1988; (2) the survey for 2007 does not include the variable 'CPC membership'.

Source: Authors' computations based on CHIP urban surveys. 
Table A2: Composition of wage earners: 1988, 1995, 2002, 2007 and 2013 (\%)

\begin{tabular}{|c|c|c|c|c|c|c|}
\hline & & 1988 & 1995 & 2002 & 2007 & 2013 \\
\hline \multirow[t]{5}{*}{ Age } & $16-25$ & 15.8 & 10.9 & 6.7 & 5.7 & 6.1 \\
\hline & $26-35$ & 29.2 & 24.3 & 22.2 & 21.2 & 24.8 \\
\hline & $36-45$ & 30.9 & 41.1 & 37.3 & 39.3 & 33.0 \\
\hline & $46-55$ & 19.9 & 20.2 & 30.1 & 27.8 & 27.2 \\
\hline & $56+$ & 4.0 & 3.6 & 3.7 & 6.0 & 8.8 \\
\hline \multirow[t]{2}{*}{ Gender } & Female & 47.7 & 46.9 & 44.4 & 45.0 & 43.4 \\
\hline & Male & 52.3 & 53.1 & 55.6 & 55.0 & 56.6 \\
\hline \multirow[t]{5}{*}{ Education } & Primary or lower & 11.9 & 5.3 & 2.6 & 2.0 & 5.2 \\
\hline & Junior middle & 38.6 & 30.1 & 21.7 & 17.4 & 22.9 \\
\hline & Senior middle & 36.0 & 40.9 & 42.1 & 37.4 & 31.2 \\
\hline & Technical & 6.8 & 16.0 & 23.2 & 27.4 & 20.3 \\
\hline & University or higher & 6.5 & 7.6 & 10.4 & 15.8 & 20.5 \\
\hline \multirow[t]{2}{*}{ Marriage } & Not married & 0.0 & 12.6 & 12.0 & 12.4 & 14.1 \\
\hline & Married & 100.0 & 87.4 & 88.0 & 87.6 & 85.9 \\
\hline \multirow[t]{2}{*}{ Ethnicity } & Majority & 95.6 & 96.7 & 97.1 & 97.5 & 96.3 \\
\hline & Minority & 4.4 & 3.3 & 2.9 & 2.5 & 3.7 \\
\hline \multirow[t]{2}{*}{ CPC membership } & Not member & 75.6 & 74.9 & 69.6 & 0.0 & 77.6 \\
\hline & Member & 24.4 & 25.1 & 30.4 & 100.0 & 22.4 \\
\hline \multirow[t]{5}{*}{ Ownership of work unit } & State & 79.2 & 80.2 & 65.1 & 55.7 & 44.1 \\
\hline & Collective & 20.0 & 16.1 & 11.1 & 8.5 & 4.8 \\
\hline & Foreign & 0.4 & 1.7 & 2.5 & 2.9 & 3.9 \\
\hline & Private & 0.1 & 0.9 & 9.3 & 23.2 & 39.7 \\
\hline & Others & 0.3 & 1.1 & 12.1 & 9.8 & 7.4 \\
\hline \multirow[t]{6}{*}{ Occupation } & Manager & 6.8 & 11.4 & 11.4 & 5.3 & 6.6 \\
\hline & Professional & 16.2 & 22.6 & 22.7 & 19.2 & 19.4 \\
\hline & Clerk & 24.2 & 21.3 & 22.3 & 35.7 & 19.6 \\
\hline & Skilled worker & 16.8 & 22.4 & 19.3 & 18.9 & 23.0 \\
\hline & Unskilled worker & 9.3 & 17.4 & 22.1 & 16.8 & 25.7 \\
\hline & Other & 26.7 & 4.7 & 2.2 & 4.1 & 5.6 \\
\hline \multirow[t]{14}{*}{ Industry } & Agriculture & 1.1 & 1.6 & 1.2 & 0.8 & 1.2 \\
\hline & Mining & 3.6 & 1.1 & 2.1 & 1.0 & 2.8 \\
\hline & Manufacturing & 43.1 & 42.8 & 27.3 & 20.4 & 18.1 \\
\hline & Construction & 3.6 & 3.2 & 3.5 & 2.9 & 5.4 \\
\hline & Wholesale, retail, and restaurant trades & 13.9 & 14.3 & 10.2 & 11.8 & 13.1 \\
\hline & $\begin{array}{l}\text { Transportation, storage, post and } \\
\text { telecommunication }\end{array}$ & 6.8 & 5.3 & 8.1 & 8.0 & 7.2 \\
\hline & Finance and insurance & 1.6 & 2.0 & 3.1 & 3.1 & 3.2 \\
\hline & Real estate & 1.6 & 4.0 & 1.4 & 2.0 & 1.2 \\
\hline & $\begin{array}{l}\text { Scientific research, professional, } \\
\text { information, computer, and technical } \\
\text { services }\end{array}$ & 2.4 & 2.0 & 1.8 & 4.6 & 4.2 \\
\hline & $\begin{array}{l}\text { Residential, leasing, and business services; } \\
\text { water, environment, and public facility } \\
\text { services }\end{array}$ & 0.9 & 0.2 & 9.6 & 13.7 & 15.2 \\
\hline & $\begin{array}{l}\text { Education, culture, sports, and } \\
\text { entertainment }\end{array}$ & 7.3 & 7.2 & 9.3 & 8.7 & 9.6 \\
\hline & $\begin{array}{l}\text { Health industries, social security, and social } \\
\text { work }\end{array}$ & 4.6 & 4.4 & 5.1 & 4.2 & 4.3 \\
\hline & $\begin{array}{l}\text { Public management, social organizations, } \\
\text { and governments }\end{array}$ & 8.5 & 11.3 & 11.9 & 15.4 & 11.6 \\
\hline & Other & 0.8 & 0.6 & 5.5 & 3.2 & 2.9 \\
\hline \multirow[t]{2}{*}{ Region } & Coastal & 30.0 & 33.2 & 38.7 & 31.6 & 35.9 \\
\hline & Central & 33.5 & 29.5 & 27.4 & 31.9 & 34.8 \\
\hline
\end{tabular}




\begin{tabular}{llrrrrr}
\hline & Western & 22.2 & 24.4 & 24.1 & 28.5 & 24.0 \\
& Northeastern & 14.3 & 12.8 & 9.8 & 7.9 & 5.3 \\
Age & Imean years & 37.2 & 38.7 & 40.7 & 41.5 & 41.3 \\
Education & /mean years & 10.5 & 10.8 & 11.5 & 12.8 & 12.9 \\
Number of observations & & 12,069 & 16,715 & 20,609 & 20,118 & 13,044 \\
\hline
\end{tabular}

Note: Sample weightings are applied.

Source: Authors' computations based on CHIP urban surveys.

Table A3 Incidence of low earnings by characteristics (\%)

\begin{tabular}{|c|c|c|c|c|c|c|}
\hline & & 1988 & 1995 & 2002 & 2007 & 2013 \\
\hline \multirow[t]{5}{*}{ Age } & $16-25$ & 54.6 & 51.3 & 51.1 & 45.3 & 46.7 \\
\hline & $26-35$ & 15.6 & 27.6 & 30.2 & 26.0 & 24.8 \\
\hline & $36-45$ & 7.0 & 15.7 & 24.3 & 27.3 & 20.5 \\
\hline & $46-55$ & 5.5 & 12.6 & 23.1 & 28.1 & 30.1 \\
\hline & $56+$ & 6.3 & 9.5 & 30.0 & 36.4 & 40.8 \\
\hline \multirow[t]{2}{*}{ Gender } & Female & 21.5 & 26.8 & 35.0 & 38.1 & 35.5 \\
\hline & Male & 12.3 & 17.0 & 21.1 & 21.2 & 21.5 \\
\hline \multirow[t]{5}{*}{ Education } & Primary or lower & 19.0 & 31.0 & 50.9 & 55.7 & 54.0 \\
\hline & Junior middle & 18.3 & 27.0 & 41.7 & 47.9 & 40.7 \\
\hline & Senior middle & 18.2 & 22.7 & 29.1 & 33.8 & 30.4 \\
\hline & Technical & 7.7 & 13.1 & 16.2 & 19.5 & 19.5 \\
\hline & University or higher & 3.5 & 6.0 & 8.6 & 8.8 & 9.8 \\
\hline \multirow[t]{2}{*}{ Marriage } & Not married & & 45.2 & 43.9 & 40.1 & 38.4 \\
\hline & Married & 16.7 & 18.2 & 25.0 & 27.2 & 25.8 \\
\hline \multirow[t]{4}{*}{ Marriage*gender } & Not married male & & 44.5 & 40.7 & 37.0 & 35.5 \\
\hline & Married male & 12.3 & 12.9 & 18.7 & 19.2 & 19.3 \\
\hline & Not married female & & 45.9 & 47.1 & 43.3 & 41.7 \\
\hline & Married female & 21.5 & 24.2 & 33.1 & 37.2 & 34.4 \\
\hline \multirow[t]{2}{*}{ Ethnic status } & Ethnic majority & 16.7 & 21.4 & 27.3 & 28.7 & 27.4 \\
\hline & Ethnic minority & 17.7 & 26.7 & 26.0 & 32.7 & 31.5 \\
\hline \multirow[t]{2}{*}{ CPC membership } & Not CPC member & 21.2 & 26.0 & 32.7 & & 31.0 \\
\hline & CPC member & 2.7 & 8.4 & 14.8 & 28.8 & 15.5 \\
\hline \multirow[t]{4}{*}{ Contract } & Fixed contract & 12.4 & 18.4 & 17.7 & 28.8 & 11.0 \\
\hline & Long-term contract & 30.6 & 30.2 & 27.5 & & 18.9 \\
\hline & Short-term contract & 69.1 & 38.2 & 41.8 & & 40.5 \\
\hline & No contract & 38.2 & 44.7 & 53.9 & & 48.5 \\
\hline \multirow[t]{5}{*}{ Ownership } & State & 12.7 & 18.5 & 20.5 & 17.3 & 15.9 \\
\hline & Collective & 31.5 & 37.9 & 39.2 & 40.5 & 33.4 \\
\hline & Foreign owned & 19.0 & 13.5 & 15.2 & 23.5 & 13.9 \\
\hline & Private owned & 56.4 & 34.6 & 47.0 & 38.8 & 37.1 \\
\hline & Other & 60.3 & 11.7 & 40.1 & 62.3 & 48.8 \\
\hline \multirow[t]{7}{*}{ Occupation } & Manager & 1.0 & 7.0 & 8.3 & 8.5 & 15.0 \\
\hline & Professional & 5.9 & 11.1 & 14.5 & 13.3 & 15.2 \\
\hline & Clerk & 11.1 & 20.8 & 23.2 & 22.8 & 21.7 \\
\hline & Skilled worker & 29.2 & 25.3 & 30.3 & 34.4 & 28.3 \\
\hline & Unskilled worker & 20.8 & 36.9 & 49.5 & 53.6 & 42.1 \\
\hline & Other & 23.0 & 37.1 & 48.4 & 53.0 & 36.1 \\
\hline & Agriculture & 15.0 & 17.8 & 21.6 & 26.1 & 45.4 \\
\hline
\end{tabular}




\begin{tabular}{|c|c|c|c|c|c|c|}
\hline \multicolumn{7}{|l|}{ Industry } \\
\hline & Mining & 20.8 & 8.7 & 20.3 & 17.9 & 23.4 \\
\hline & Manufacturing & 19.4 & 24.0 & 33.7 & 30.3 & 24.8 \\
\hline & Construction & 18.1 & 26.1 & 27.1 & 29.6 & 27.0 \\
\hline & Wholesale, retail, and restaurant trades & 20.6 & 32.0 & 41.3 & 45.9 & 43.4 \\
\hline & $\begin{array}{l}\text { Transportation, storage, post and } \\
\text { telecommunication }\end{array}$ & 12.5 & 20.8 & 21.9 & 23.1 & 21.4 \\
\hline & Finance and insurance & 14.3 & 17.7 & 14.6 & 12.9 & 14.1 \\
\hline & Real estate & 23.2 & 25.6 & 17.1 & 25.2 & 18.2 \\
\hline & $\begin{array}{l}\text { Scientific research, professional, information, } \\
\text { computer, and technical services }\end{array}$ & 7.8 & 5.1 & 15.1 & 16.4 & 20.7 \\
\hline & $\begin{array}{l}\text { Residential, leasing, business services; water, } \\
\text { environment, and public facility services }\end{array}$ & 36.1 & 0.0 & 48.6 & 50.0 & 42.7 \\
\hline & Education, culture, sports, and entertainment & 8.8 & 10.9 & 12.8 & 13.0 & 16.3 \\
\hline & Health industries, social security, and social work & 8.7 & 12.4 & 12.2 & 23.3 & 26.6 \\
\hline & $\begin{array}{l}\text { Public management, social organizations, and } \\
\text { governments }\end{array}$ & 6.6 & 12.8 & 14.0 & 19.6 & 16.3 \\
\hline & Other & 32.8 & 29.7 & 24.0 & 13.4 & 20.2 \\
\hline \multirow[t]{4}{*}{ Region } & Coastal & 9.8 & 10.6 & 18.8 & 16.8 & 20.3 \\
\hline & Central & 25.1 & 32.3 & 33.1 & 30.6 & 30.3 \\
\hline & Western & 14.8 & 19.9 & 30.7 & 35.7 & 32.1 \\
\hline & Northeastern & 14.5 & 28.7 & 35.7 & 44.6 & 38.2 \\
\hline
\end{tabular}

Note: (1) All the figures are adjusted with weighting; (2) the 'marriage' variable is missed in 1988, while in 2007 'CPC membership' and 'contract' information are missed.

Source: Authors computations based on CHIP urban surveys. 